\title{
Magneto-biostratigraphic age constraints on the palaeoenvironmental evolution of the South Caspian basin during the Early-Middle Pleistocene (Kura basin, Azerbaijan)
}

\author{
Sergei Lazarev ${ }^{\text {a, }}$, Elisabeth L. Jorissen ${ }^{\text {a }}$, Sabrina van de Velde ${ }^{\text {, }}$, Lea Rausch ${ }^{\text {, }}$, \\ Marius Stoica ${ }^{c}$, Frank P. Wesselingh ${ }^{\mathrm{b}}$, Christiaan G.C. Van Baak ${ }^{\mathrm{d}}$, Tamara A. Yanina ${ }^{\mathrm{e}}$, \\ Elmira Aliyeva ${ }^{\mathrm{f}}$, Wout Krijgsman ${ }^{\mathrm{a}}$ \\ a Paleomagnetic Laboratory «Fort Hoofddijk», Department of Earth Sciences, Utrecht University, Budapestlaan 17, 3584CD, Utrecht, the Netherlands \\ ${ }^{\mathrm{b}}$ Naturalis Biodiversity Center, P.O. Box 9517, 2300RA, Leiden, the Netherlands \\ ${ }^{c}$ Department of Geology, Faculty of Geology and Geophysics, Bucharest University, Bălcescu Bd. 1, 010041, Bucharest, Romania \\ d CASP, West Building, Madingley Rise, Madingley Road, CB3 OUD, Cambridge, United Kingdom

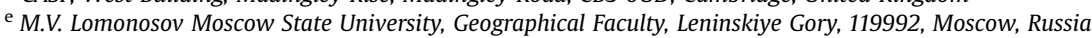 \\ ${ }^{\mathrm{f}}$ Institute of Geology ANAS, H. Javid av., 29A, 1143, Baku, Azerbaijan
}

\section{A R T I C L E I N F O}

\section{Article history:}

Received 21 January 2019

Received in revised form 19 August 2019

Accepted 21 August 2019

Available online 14 September 2019

\section{Keywords:}

Early - Middle Pleistocene

Caspian Sea

Magnetostratigraphy

Biostratigraphy

Akchagylian

Apsheronian

Bakunian

Kura Basin

Mollusc fauna

Ostracods

\begin{abstract}
A B S T R A C T
The sedimentary record of the Caspian Basin is an exceptional archive for the palaeoenvironmental, palaeoclimatic and biodiversity changes of continental Eurasia. During the Pliocene-Pleistocene, the Caspian Basin was mostly isolated but experienced large lake level fluctuations and short episodes of connection with the open ocean as well as the Black Sea Basin. A series of turnover events shaped a faunal record that forms the backbone of the Caspian geological time scale. The precise ages of these events are still highly debated, mostly due to the lack of well-dated sections. Here, we provide an integrated magneto-biostratigraphic age model for two sections from the Kura Basin - Goychay and Hajigabul. Our results reveal several major intervals with elevated salinity, associated with mesohaline faunas, and propose the following age constraints: 1) The Productive Series-Akchagylian boundary is marked by a marine transgression from the open ocean that occurred around the Gauss-Matuyama reversal ( 2.7-2.6 Ma); 2) The Akchagylian-Apsheronian transition is characterized by a regression event and introduction of a new, "Pontocaspian" mollusc assemblage, dated within the Reunion subchron $(\sim 2.13 \mathrm{Ma})$. The ostracod assemblages of the two sections do not show a major faunal turnover here; 3 ) The early Bakunian transgression occurs after the upper Apsheronian lowstand (0.85-0.83 Ma). We conclude that major transitions in the age-indicative mollusc groups sometimes occur at different time intervals (i.e. diachronic) and are highly depended on the local depositional environments. A highresolution interdisciplinary approach on sections outside the Kura Basin is required to better understand the potential diachroneity of these turnover events in the entire Caspian Basin.
\end{abstract}

๑) 2019 Elsevier Ltd. All rights reserved.

\section{Introduction}

The Caspian Sea is an endorheic basin, located between Eastern Europe and Central Asia. Even though the Caspian Sea has marine aspects (salinity, particular faunas), it is technically a long-lived lake and it is the largest lake in the world. The Caspian Basin became isolated from the Paratethys Sea during the latest Miocene

\footnotetext{
* Corresponding author.

E-mail address: s.lazarev@uu.nl (S. Lazarev).
}

(Popov et al., 2006; van Baak et al., 2017). Since that time, the Caspian Sea went through periods of dramatic lake-level drops and spectacular expansions. The Caspian Sea was mostly isolated but periodically connected to the Black Sea Basin and global ocean (Krijgsman et al., 2019). Consequently, a unique fauna evolved in the Caspian Basin through a series of strong turnover events. The sedimentary record of the Caspian Sea Basin provides a detailed geological archive to study these faunal changes and the coeval climatic and environmental history of Eurasia.

The most complete geological successions crop out in the South 
Caspian Basin (including the Kura Basin and the West Turkmenian Depression). Here, active tectonic uplift of the basin margins and hinterlands, accompanied with high subsidence rates in the basin, preconditioned accumulation of kilometres of sediments since the late Miocene (Allen et al., 2002; Morton et al., 2003; Forte et al., 2015). A succession of endemic species (Trubikhin, 1977) that occupied the anomalohaline ("brackish") lakes of the South Caspian Basin has been used to erect regional stratigraphic schemes. The Pliocene - Middle Pleistocene succession of the South Caspian Basin is subdivided into several regional stratigraphic stages: Akchagylian, Apsheronian, Bakunian and Khazarian (Muratov and Nevesskaya, 1986; Jones and Simmons, 1997). These regional stages have been uniformly applied to the entire Caspian Basin (Nevesskaya et al., 2004; Zastrozhnov et al., 2013). Yet the tectonosedimentary histories of the North, Middle and South Caspian basins have been very different and might have resulted in the diachronous evolution of depositional environments and associated faunas (e.g., Forte et al., 2015).

Furthermore, preservation potential and lateral variability of habitats, which may affect the definition of regional biostratigraphic stages, remain largely unexplored. Well-preserved deep water faunas are often lacking and in shallower settings faunas may respond to local paleoenvironmental change rather than represent basin-wide synchronous turnover events (Markova, 1962; Magyar et al., 2013). In this paper we study two long sections in Azerbaijan covering the Productive Series to the Khazarian regional stages, straddling the interval $\sim 3-0.5 \mathrm{Ma}$. The Goychay and Hajigabul sections are located in proximal and distal settings in the Kura Basin, respectively.

The aim of this study is to characterize major depositional units and combine magnetostratigraphic and biostratigraphic (molluscs and ostracods) approaches to develop an integrated stratigraphic framework, which will facilitate the identification of major drivers of regional paleoenvironmental changes.

\section{Geological background}

\subsection{The South Caspian Basin: setting and structure}

The Caspian Sea is elongated in a meridional direction and overlies several tectonic-structural zones, forming three subbasins: North, Middle (Central) and South Caspian basins (Fig. 1A). The North Caspian Basin is a depression that was formed in the Late Proterozoic (Khain et al., 2004; Khain and Popkov, 2009) on the East European platform. Its sedimentary infill contains several distinctive complexes: Early Palaeozoic, Devonian Permian, Permian - Triassic and Jurassic - Quaternary. The basement of the Middle Caspian Basin consists of Late Proterozoic metamorphic rocks of the Scythian Platform with a complex of Mesozoic and Cenozoic sedimentary rocks on top (Khain et al., 2004; Green et al., 2009). The South Caspian Basin is linked to the Alpine-Himalayan orogenic belt of the Greater Caucasus and forms the most tectonically active part of the Caspian Sea (Jackson et al., 2002). It consists of the South Caspian Depression and a complex of surrounding foredeep basins: the Kura, West Turkmenia and Absheron-Gobustan depressions (Brunet et al., 2003; Khain et al., 2004; Forte et al., 2013, 2015). The basement of the South Caspian Depression is considered to be either oceanic crust or attenuated, high velocity continental crust (Mangino and Priestley, 1998). The complex of sedimentary rocks that overlies the basement has a thickness of up to $20 \mathrm{~km}$, most of which accumulated during latest Miocene - Pliocene (Allen et al., 2002; Brunet et al., 2003; Morton et al., 2003; Green et al., 2009).

The Kura Basin is the western extension of the South Caspian Basin and the foreland basin between the Lesser and Greater
Caucasus mountain ranges (Fig. 1B). Because of the extreme depth (up to $20 \mathrm{~km}$ ) the composition of the basement of the Kura Basin is poorly known. It may be a westward continuation of the South Caspian Basin basement (Zonenshain and Le Pichon, 1986), containing Early Palaeozoic crystalline rocks (Azizbekov, 1972) and/or the remnant of a Mesozoic island arc (Nadirov et al., 1997). The late Cenozoic history of the Kura Basin is closely linked to the amplification of the Arabian - Eurasian collision that caused progradation of the Kura thrust fold belt (Forte et al., 2010). This belt accommodated most of the post five Ma shortening, which is expressed in a series of well-exposed sedimentary successions, located along the northern flank of the Kura Basin. This late Cenozoic sedimentary sequence is about $5-7 \mathrm{~km}$ thick and is similar to that found in the South Caspian Basin (Mangino and Priestley, 1998; Allen et al., 2002; Forte et al., 2010).

\subsection{Caspian Sea: from Paratethys to an isolated basin}

The Caspian Sea became isolated during the fragmentation of the Paratethys, a large epicontinental sea reaching in the Oligocene from the Molasse Basin in France in the West to the Tien Shan mountains in western China in the East (Laskarev, 1924). The Paratethys has been shrinking in size throughout its Neogene and Quaternary history due to the ongoing collision between the African, Arabian and Eurasian plates (Rögl, 1999; Schulz et al., 2005; Popov et al., 2006). Isolation of the Caspian Sea from other Paratethyan basins occurred during the latest Miocene, around 5.6-5.5 Ma (Allen et al., 2002, 2003; Jackson et al., 2002). At that time, a complex combination of climatic and tectonic factors led to a major Paratethys sea-level drop (Krijgsman et al., 2010; van Baak, 2015; van Baak et al., 2017). Consequently, intensification of the Caucasian orogeny provoked a permanent closure of the Ciscaucasian Strait and thus, isolation of the Caspian Basin from the Euxinian (Black Sea) Basin (Popov et al., 2010).

During the early Pliocene, both climatic and tectonic factors contributed to a large lake-level drop in the Caspian Basin (Kroonenberg et al., 2005). The basin reduced in size to the South Caspian Depression and deep river canyons eroded into the desiccated North and Central Caspian basins (Kroonenberg et al., 2005). The Palaeo-Volga, Palaeo-Kura and Palaeo-Amu-Darya deltas reached the South Caspian Basin and locally deposited about 7-8 km of sediments (Morton et al., 2003; Green et al., 2009; Abdullayev et al., 2017). This Pliocene lake-level lowstand was initiated around 5.3 Ma and had resulted in deposition of the Productive Series - a sequence of interbedded and regionally continuous lacustrine mudstones and fluvio-deltaic sandstones that form main hydrocarbon reservoirs in the South Caspian region (Aliyeva, 2005; Kroonenberg et al., 2005; Vincent et al., 2010). The Productive Series was terminated by the late Pliocene Akchagylian transgression (Nevesskaya and Trubikhin, 1984; Popov et al., 2006; Green et al., 2009).

\subsection{Late Pliocene - Early Pleistocene regional stages and boundaries}

From the late Pliocene onwards, a succession of anomalohaline lake stages with characteristic endemic faunal suites developed (Nevesskaya and Trubikhin, 1984; Danukalova, 1996). The stratigraphic boundaries of these stages are subject of scientific debate (Krijgsman et al., 2019) The first research on the Caspian stratigraphy started at the end of the 19th century with the works of Sjögren, Andrusov and Barbot-de-Marni (Vereshchagin, 1982). Ever since, the definitions of stratigraphic units have been discussed, further documented and updated (Andrusov, 1918; Borissjak, 1937; Ali-Zade, 1961; Muratov and Nevesskaya, 1986). In the 1950's - 


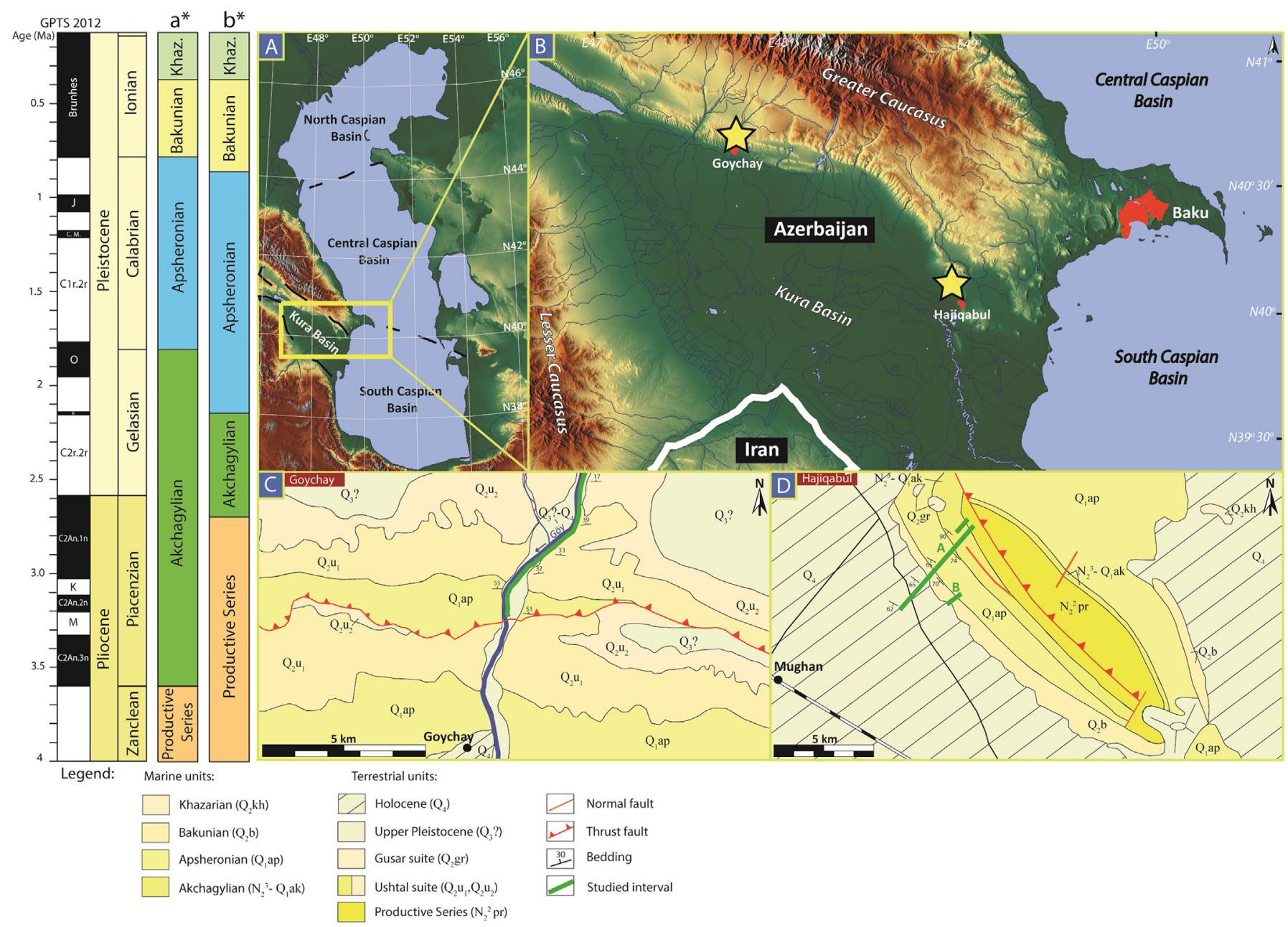

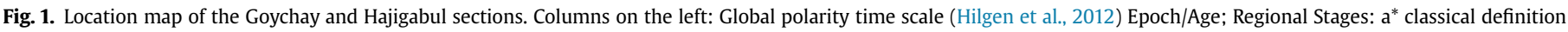

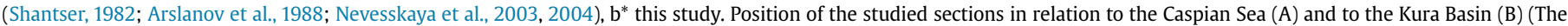
map base is taken from www.maps-for-free.com); Geological maps for the Goychay section (C) and the Hajigabul section (D) modified after Bairamov et al. (2008).

1970's, magnetostratigraphic analyses in the South Caspian Basin contributed to an age model for the late Pliocene - Pleistocene regional stages of the Caspian region (Khramov, 1960, 1963; Trubikhin, 1977; Pevzner, 1986).

The Lower - Middle Pleistocene geological record of the Caspian region comprises four regional stages: Akchagylian, Apsheronian, Bakunian and Khazarian (Krijgsman et al., 2019). The Akchagylian Stage was defined by Andrusov on the Krasnovodskiy peninsula (Turkmenian coast) and named after the "Akchagyl hill" (Andrusov, 1902; Ali-Zade, 1961; Muratov and Nevesskaya, 1986). The lectostratotype (the Ushak well) is also located on the Krasnovodskiy peninsula, in Turkmenistan (Ali-Zade, 1961). In the Kura Basin, the Akchagylian stage developed as a dark grey claystone unit interbedded with white ash layers (van Baak, 2015). The Akchagylian Stage represents a wide transgression event following the Productive Series lowstand phase. The lake expanded far onto the northern and western margins of the basin and refilled all subbasins like the Kura Basin, pre-Kopet-Dagh Gulf, Aral Sea, as well as the Volga and Kama deltaic plains (Muratov and Nevesskaya, 1986; Popov et al., 2006). One of the most distinguishing features in the Akchagylian is its unique endemic mollusc fauna (Paramonova, 1994; Danukalova, 1996). Characteristic mollusc species include Cerastoderma dombra, Avimactra subcaspia, Pirenella caspia, as well as species of Aktschagylia, Andrussovicardium,
Avicardium and Miricardium (Nevesskaya and Trubikhin, 1984; Paramonova, 1994; Danukalova, 1996). Microfaunas contain oligoto mesohaline ostracods of Leptocythere, Limnocythere, Loxoconcha, euryhaline Cyprideis and freshwater species of genus Candona. The most common foraminifera taxa are Bolivina, Cassidulina and Cibicides (Rozyeva, 1971; Paramonova, 1994; Alizadeh et al., 2016). During the Akchagylian a likely connection existed between the Caspian Sea and the Arctic Ocean (MordukhaiBoltovskoi, 1964; van Baak, 2015; Richards et al., 2018). However, the pathways of the connection as well as the origin of this fauna are still unclear (Hoyle et al., 2019; Krijgsman et al., 2019).

The age of the onset of the Akchagylian Stage is still under discussion (Krijgsman et al., 2019). It was commonly correlated to the lower limit of the Gauss chron at 3.6 Ma (Trubikhin, 1977). However, revision of this correlation, as well as recent data from the Kura Basin and Apsheron peninsula, suggest an age of $2.7 \mathrm{Ma}$ instead, which correlates to the upper limit of the Gauss chron (Gurarii, 2015; van Baak, 2015; Abdullayev et al., 2018; Hoyle et al., 2019).

The Apsheronian Stage was defined by Barbot-de-Marni and Simonovic (1891) and has been described in more details by Andrusov (1923). The Bayil section near Baku City was proposed as a lectostratotype (Borissjak, 1937; Vereshchagin, 1982; Muratov and Nevesskaya, 1986). In Apsheronian time, the size of the 
Caspian Sea slightly diminished compared to the previous Akchagylian stage. Apsheronian deposits almost everywhere conformably overlie Akchagylian deposits (Sidnev, 1985; Zastrozhnov et al., 2013; Alizadeh et al., 2016).

The Apsheronian mollusc fauna almost fully replaced the previous Akchagylian communities (Nevesskaya and Trubikhin, 1984). The Apsheronian mollusc fauna is dominated by cardiids, hydrobiids and dreissenids. Among them are bivalve genera Dreissena, Corbicula, Apscheronia, Monodacna, Didacna, Didacnomya and Hyrcania and the gastropod genera Turricaspia, Streptocerella and Lymnaea (Nevesskaya, 1958; Bludorova et al., 1983; Nevesskaya and Trubikhin, 1984; Muratov and Nevesskaya, 1986). Ostracod species of the genera Leptocythere and Caspiolla typify the Apsheronian (Bludorova et al., 1983; Alizadeh et al., 2016). Several of these genera occurred in the Pliocene - Early Pleistocene Black Sea Basin and were absent during the Akchagylian in the Caspian Basin. Therefore, part of the Apsheronian fauna appears to have originated in the Black Sea Basin (Bogachev, 1940; Popov, 1970; Taktakishvili, 1977).

Apsheronian deposits are usually conformably overlain by Middle Pleistocene Bakunian deposits. However, some researchers documented erosive sandy and conglomeratic deposits with freshwater mollusc and ostracod fauna on top of the Apsheronian (Svitoch and Yanina, 2007). These deposits are locally known as Tyurkyanian and represent a lowstand of the Caspian Basin at the end of the Apsheronian stage. The stratigraphic rank of Tyurkyanian is still unclear. It is considered as an independent stage (Svitoch and Yanina, 2007; Zastrozhnov et al., 2013), a suite (Vereshchagin, 1982) or as the lowermost part of Bakunian Stage (Krasnov, 1984). Here, we only focused on the subdivision of the Apsheronian and Bakunian.

The base of the Apsheronian stage is commonly correlated to the top of the Olduvai subchron at an age of $1.8 \mathrm{Ma}$ (Kochegura and Zubakov, 1978; Semenenko and Pevzner, 1979). The polarity pattern of the Duzdag section in Azerbaijan (Pevzner, 1986), however, shows that the onset of the Apsheronian is better correlated to the Reunion subchron, estimated at $2.1 \mathrm{Ma}$. This provides an alternative correlation for the Akchagylian - Apsheronian transition (see Krijgsman et al., 2019 and references therein).

The Bakunian Stage was defined by Sjögren (1891) on the Absheron Peninsula of Azerbaijan, as sedimentary strata that overlie the Apsheronian deposits (Borissjak, 1937). The Gora Bakinskogo Yarusa section and the Neftyanaya Balka section have been proposed as lectostratotypes (Yanina, 2013).

The Bakunian mollusc fauna is very distinct from the Apsheronian fauna: it is dominated by a set of particular Didacna species. The Bakunian stage is divided into two sub-stages. The lower Bakunian is characterized by a wide range of differently shaped Didacna species, like Didacna parvula and D. catillus catillus. Furthermore, Dreissena rostriformis and ostracods such as Eucypris inflata, Candoniella albicans and Cypris mandelstami (Krasnov, 1984) occur in this interval. The upper Bakunian is represented by Didacna eulachia, $D$. bakuana, $D$. rudis, $D$. carditoides coexisting with the same species occurring in the lower Bakunian (Yanina, 2013). Among typical ostracods are species of the genera Candona, Eucypris, Loxoconcha and Leptocythere (Ali-Zade, 1961; Krasnov, 1984).

Some researchers also recognise a separate Urundzhikian Stage between the Bakunian and Khazarian (Svitoch et al., 2010; Yanina, 2012, 2013). The Urundzhikian stratigraphic status is unclear, as it is considered as a stage, horizon, suite or just as a layer (Krasnov, 1984). The Urundzhikian mollusc association consists of species that are typical for the preceding Bakunian and succeeding Khazarian (Yanina, 2012). Due to all issues mentioned above, we here only use a division into Bakunian and Khazarian.
The base of the Bakunian Stage is correlated to the Matuyama Brunhes polarity reversal and is dated at $0.781 \mathrm{Ma}$ (Asadullayev and Pevzner, 1973). However, recent studies on the Xocashen section in Azerbaijan suggest a slightly older age of $0.85 \mathrm{Ma}$, corresponding to the upper part of the Matuyama (van Baak et al., 2013). Hence, the base of the Bakunian Stage is estimated between $0.78 \mathrm{Ma}-$ $0.85 \mathrm{Ma}$. In the Goychay area (Fig. 1C), the continental Ushtal suite is widely represented by alluvial deposits with a thickness up to $500 \mathrm{~m}$. This is considered to be the terrestrial analogue of Bakunian deposits (Alizadeh et al., 2016).

The Khazarian Stage was defined by Andrusov in 1913 and later clarified as strata that transgressively overlie upper Bakunian and Urundzhikian deposits in the North Caspian Basin and the Manych region (Vereshchagin, 1982). Despite several existing subdivision schemes, we follow here a subdivision into a lower and upper Khazarian that represents two successive transgressive events with different mollusc faunas (Vekilov, 1969). The lower Khazarian is characterized by the abundance of so-called trigonoidal Didacna species, such as Didacna subpyramidata, D. trigonula, D. paleotrigonoides. Furthermore, some species of the catilloidal group with Didacna subcatillus, D. dilatata and the crassoidal group with Didacna nalivkini, D. apscheronica, D. pravoslavlevi occur (Yanina, 2012). Among microfauna, most typical ostracods are Candoniella subellipsoida, Caspiolla gracilis, Leptocythere arevina, Loxoconcha endocarpa, Cytherissa cascusa, and key foraminifera are Ammonia caspica and Mayerella brotzkajae (Sedaikin, 1988; Yanko, 1989; Svitoch and Yanina, 1997). In the upper Khazarian a group of crassoidal Didacna with D. surachanica are indicative species (Fedorov, 1957; Yanina, 2012).

The lower Khazarian is correlated to the upper part of the Middle Pleistocene and dated between 400 and $260 \mathrm{ka}$. It shows normal polarities (Brunhes) and one or two short-term reverse polarity fluctuations (Saltykov, 2011). A recent review on the lower Khazarian suggests a correlation to the MIS 10 stage and an age around 0.37-0.38 Ma (Saltykov, 2011; Krijgsman et al., 2019).

A brief overview on the regional stratigraphic time scale shows that regional stages are distinct and characterized by specific faunal assemblages. However, there are still many uncertainties regarding the definition and age constraints of the stage boundaries.

\section{Material and methods}

The Goychay section (N40.684458 $\left.{ }^{\circ}, \mathrm{E} 47.759803^{\circ}\right)$ is located on the north-western margin of the Kura Basin and was previously described and logged in detail (Forte et al., 2013). A stratigraphic succession of $2200 \mathrm{~m}$ thick is exposed along the Göy River that flows southwards, cutting through a NW-SE foreland thrust fault system (Figs. 1C and 2A) (Forte et al., 2013). The Hajigabul section (N40.1270332 ${ }^{\circ}, \mathrm{E} 48.8726990^{\circ}$ ) is located to the Southeast of Goychay, $11 \mathrm{~km} \mathrm{NW}\left(330^{\circ}\right)$ from the Hajigabul city centre (also known as Adzhikabul or Hajiqabul), in a more central and deeper part of the Kura Basin (Fig. 1D). The section crops out along the Hajigabul anticline, also known as the Maliy Kharami (or Kichik Kharami) fold whose axis trends $320^{\circ} \mathrm{NW}-140^{\circ} \mathrm{SE}$. A well-exposed stratigraphic succession of $2035 \mathrm{~m}$ thick was logged in detail, with GPS coordinates taken at $5 \mathrm{~m}$ stratigraphic intervals (Fig. 2B). The interval $1560-1730 \mathrm{~m}$ was additionally studied in a neighbouring valley (Section $\mathrm{B}, \mathrm{N} 40^{\circ} 7^{\prime} 8.00^{\prime \prime}, \mathrm{E} 48^{\circ} 52^{\prime} 57.30^{\prime \prime}$ ) due to bad exposure in the main Section A (Fig. 1D).

For palaeomagnetic investigations, 142 stratigraphic levels were sampled along the Goychay section and 197 levels along the Hajigabul section. Two standard cylindrical cores were collected from each level using an electrical drill with a diamond crone, water pump and electrical generator as power supply. Each core was oriented with a measuring table and compass. A local declination of 


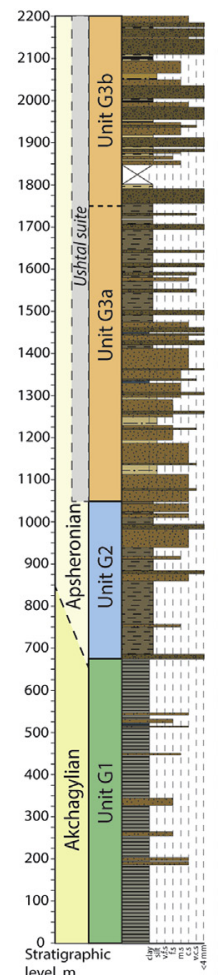

\section{A Goychay}
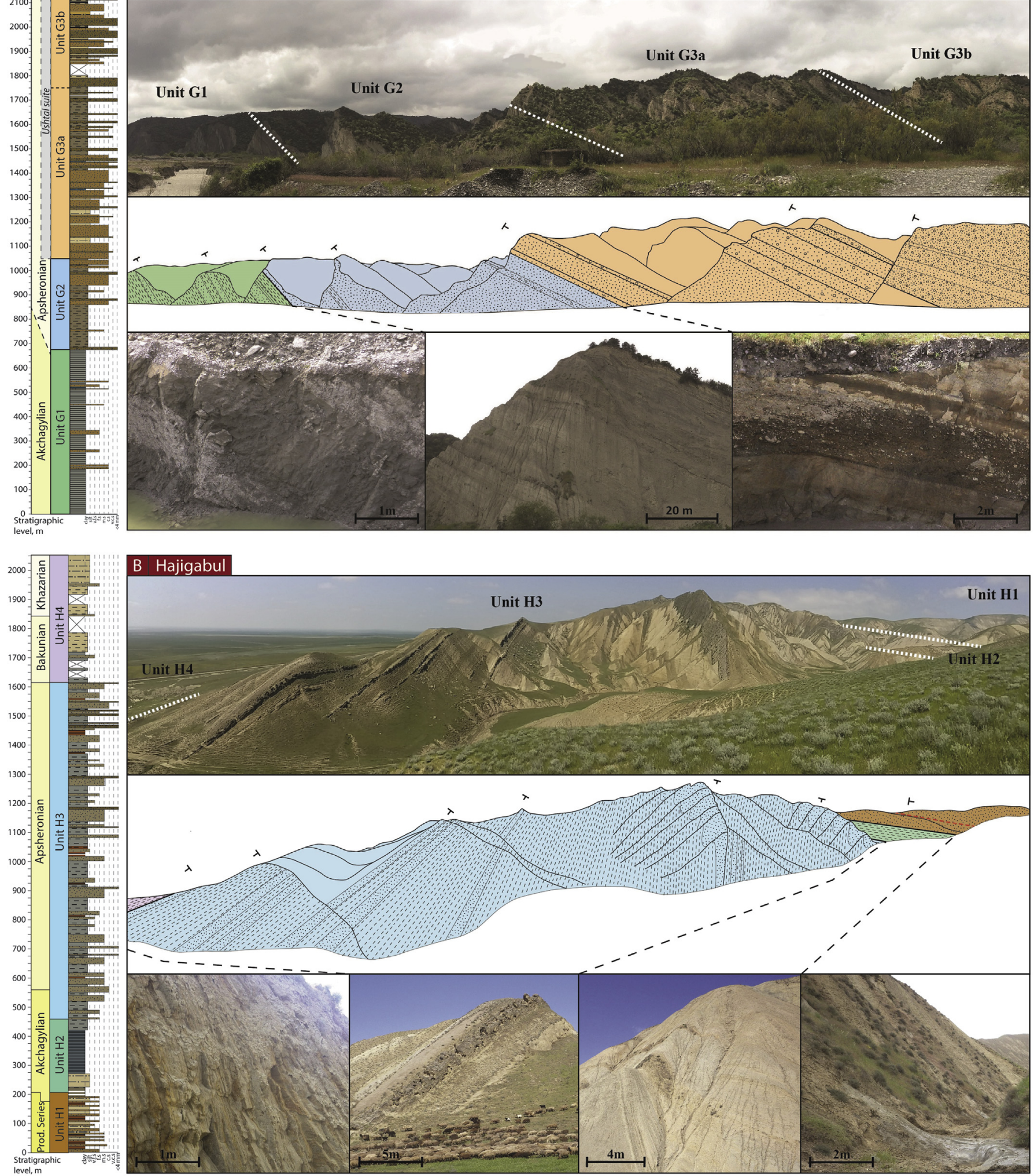

\section{B Hajigabul}

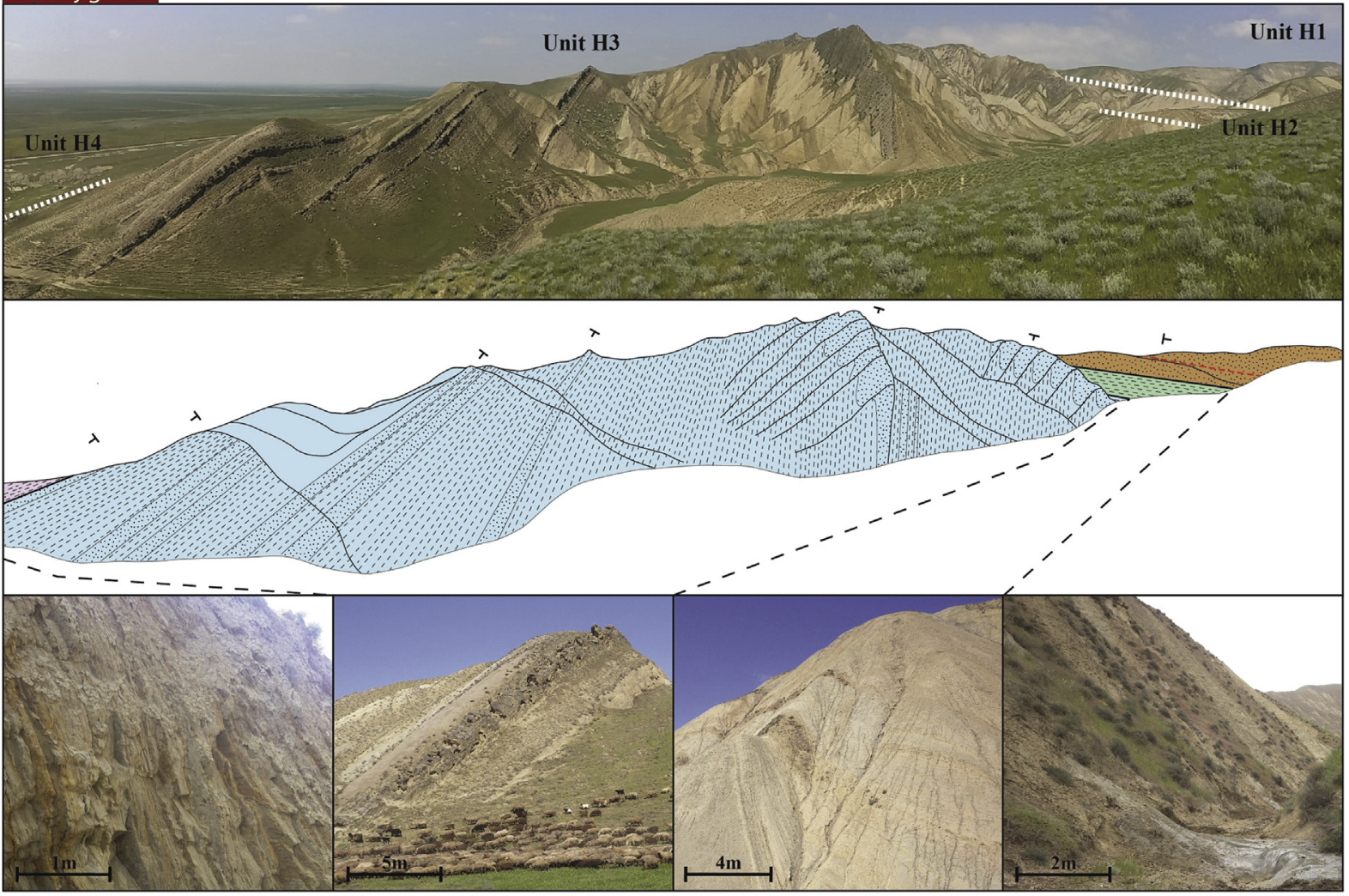

Fig. 2. Lithostratigraphic subdivision of the Goychay section (A) and the Hajigabul section (B). Logs, general view and characteristic photos of each sedimentary unit.

$6^{\circ}$ (https://www.ngdc.noaa.gov) has been added to the orientation measurements to compensate for secular variation.

Palaeomagnetic measurements were performed at the Palaeomagnetic Laboratory "Fort Hoofddijk" at Utrecht University, the
Netherlands. In total 218 samples were stepwise thermally demagnetized with increments of $30-40{ }^{\circ} \mathrm{C}$ in zero field magnetic conditions. Natural remanent magnetization (NRM) was measured on a horizontal 2G Enterprises DC SQUID cryogenic magnetometer 
(noise level $3 \times 10^{-12} \mathrm{Am}^{2}$ ). Each sample was measured in multiple positions and incrementally heated up to a maximum temperature of $680^{\circ} \mathrm{C}$, or to a lower temperature where the remanent magnetization was less than $10 \%$ of the initial NRM. In addition, 23 samples from the Hajigabul section were demagnetized in alternating field (AF) from 0 to $100 \mathrm{mT}$. Measurements in alternating field (AF) were performed on a robotized sample handler controller attached to a horizontal 2G Enterprises DC SQUID cryogenic magnetometer (Mullender et al., 2016). Bulk magnetic susceptibility measurements were performed on an AGICO Kappabridge MFK1-FA at room temperature and applied field of $200 \mathrm{~A} / \mathrm{m}$. To identify magnetic carriers, 10 samples from both sections were measured for thermomagnetic properties in air on a horizontal type Curie balance (noise level $5 \times 10^{-9} \mathrm{Am}^{2}$ ) (Mullender et al., 1993). Interpretation of measured directions was carried out using the online platform Paleomagnetism.org (Koymans et al., 2016). The supplementary material files associated with this paper contain a catalogue with information about all taken and analysed samples (Supplementary 1,2 ) as well as interpretation of palaeomagnetic data (directions and statistics) that can be uploaded on Paleomagnetism.org (Supplementary $3-8)$.

In our paper, we refer to the Geomagnetic Polarity Time Scale (GPTS) 2012 (Hilgen et al., 2012) for correlation of magnetic polarity patterns. We also used the last improvement on the age of the Cobb Mountain subchron (Channell, 2017). For the calculation of sedimentation rates, we used the ratio of the thickness of polarity intervals in the section to the actual duration of the corresponding chron in GTS2012. The boundary between normal and reversed intervals has been set at the middle point between two measured samples with different polarity. Uncertainty levels were calculated by assuming the upper- and lowermost possible stratigraphic position of the polarity zone. For incomplete chrons we extrapolate sedimentation rate from the underlying, relatively long, complete chrons with similar lithology/depositional environments.

For micropalaeontological study, 46 samples from Goychay and 57 samples from Hajigabul section have been analysed for ostracods and foraminifera. Samples were processed using a standard micropalaeontological approach, sieved over $63 \mu \mathrm{m}$ sieves and handpicked under a microscope following procedures outlined in Stoica et al. (2013). We also studied the fossil mollusc assemblages in both sections by making field observations and taking hand samples. In total, 10 samples in Goychay and 61 samples in Hajigabul have been analysed for mollusc fauna. These samples were typically $0.5-1 \mathrm{~kg}$ and were washed over $1 \mathrm{~mm}$ sieves and picked. For identifications, Andrusov (1923) and Kolesnikov (1950) have been used. For estimation of water salinity, we used three salinity intervals from the Venetian classification: freshwater $(0-0.5 \%)$, oligohaline $(0.5-5 \%$ ) and mesohaline $(5-18 \% 0)$.

\section{Results}

\subsection{Goychay section}

\subsubsection{Lithological description}

The Goychay section has been subdivided in three depositional units (Fig. 2A). Unit G1 $(0-675 \mathrm{~m})$ represents a thick clay-dominated interval at the base of the section. The lowermost part of Unit G1 $(0-120 \mathrm{~m})$ is represented by thinly laminated grey claystones. Higher in the section, grey claystones alternate with rare centimetre-scale layers of brownish siltstones and coarse sandstones. The sandstones display millimetre-scale horizontal laminae and centimetre-scale wavy bedding, sigmoidal crossstratification and centimetre-scale scours. These sedimentary structures are often separated by dark-grey organic-rich clay partings. Locally, centimetre-scale soft sediment deformation structures are present. In addition, we observed a few levels rich in molluscs. Unit G1 is interpreted as a distal depositional environment with claystones deposited out of suspension, occasionally disrupted by sandstones transported by small density underflow currents into open-waters. Towards the top of Unit G1, sandstone layers become coarser and more frequent, indicating a regressive/ prograding trend.

Unit G2 (675-1050 m) is composed of brownish-grey mudstones recurrently alternating with yellowish-brown siltstones and conglomeratic sandstones (Fig. 2A). Its lower boundary is marked by the appearance of the first conglomeratic layer. Sandstones are deposited in meter-to decametre-thick beds, which often display an erosive base. Sandstone beds include decimetre-to meter-scale sigmoidal cross-stratification, decimetre-scale scours and millimetre-scale horizontal laminations. Sedimentary structures are typically separated by finer grained sandstones or by dark-grey organic-rich clay partings. Some anomalohaline (brackish) and freshwater mollusc species were found in these deposits. Unit G2 records sediments deposited out of suspension, frequently disturbed by large density underflow currents. This interval was subject to higher energy outflows in a more proximal depositional environment compared to Unit G1. The sedimentary succession displays coarser and thicker sandstone beds towards the top, representing a regressive/prograding trend.

Unit G3 can be subdivided into two subunits. The subunit G3a (1050-1750 m) consists of brownish fine to conglomeratic sandstones, deposited in meter-to decametre-thick erosive layers (Fig. 2A). Its lower boundary is defined by the disappearance of distal claystones. Sandstone layers often contain lag deposits at their base with normal grading and meter-scale sigmoidal crossstratification. Sedimentary structures are typically separated by finer grained sandstone partings. Sandstone beds usually form decimetre-wide channels. They are intercalated with yellowishbrown mudstones and siltstones. Unit G3a is interpreted as being deposited in fluvial environments.

The subunit G3b (1750-2200 m) consists of conglomeratic beds interbedded with dark grey and reddish brown claystones. Dark grey claystones are enriched in millimetre-to centimetre-scale organic fragments. They include centimetre-scale vertical roots and contain some centimetre-thick coal layers, as well as terrestrial flat gastropods. The sandstones were deposited under very high energies in fluvial channels. In between these fluvial channels, organic-rich fine-grained sediments were deposited out of suspension in flood plains. Thereby, subunit G3b was deposited in subaerially exposed setting of fluvial and floodplain environments. The general sedimentary succession recorded along the Goychay section thus highlights a regressional trend from distal open-water to proximal fluvial and floodplain depositional environments.

\subsubsection{Microfauna (ostracods and foraminifera)}

Throughout the Goychay section, several ostracod assemblages have been identified, representing frequent variations between freshwater, oligohaline and mesohaline environments. The lowermost part of Unit G1 (77.5-99.4 m) is dominated by mesohaline assemblages with the foraminifera Ammonia sp. and ostracods like Loxoconcha eichwaldi, L. petasa, L. babazananica, Eucythere naphtatscholana, Tyrrhenocythere bailovi, Amnicythere ex. gr. andrussovi, A. cymbula, A. monotuberculata, A. alveotuberculata, Cyprideis torosa and Cytherissa bogatschovi (Fig. 3). Higher in the section, foraminifera disappear and the ostracod assemblages reduce in the number of taxa, suggesting oligohaline environments (Fig. 3). Samples between 267 and $285 \mathrm{~m}$ are barren in microfauna. After this barren zone, the diverse anomalohaline ostracod assemblages alternate with short intervals that contain exclusively freshwater species. Freshwater assemblages include mainly Ilyocypris bradyi 


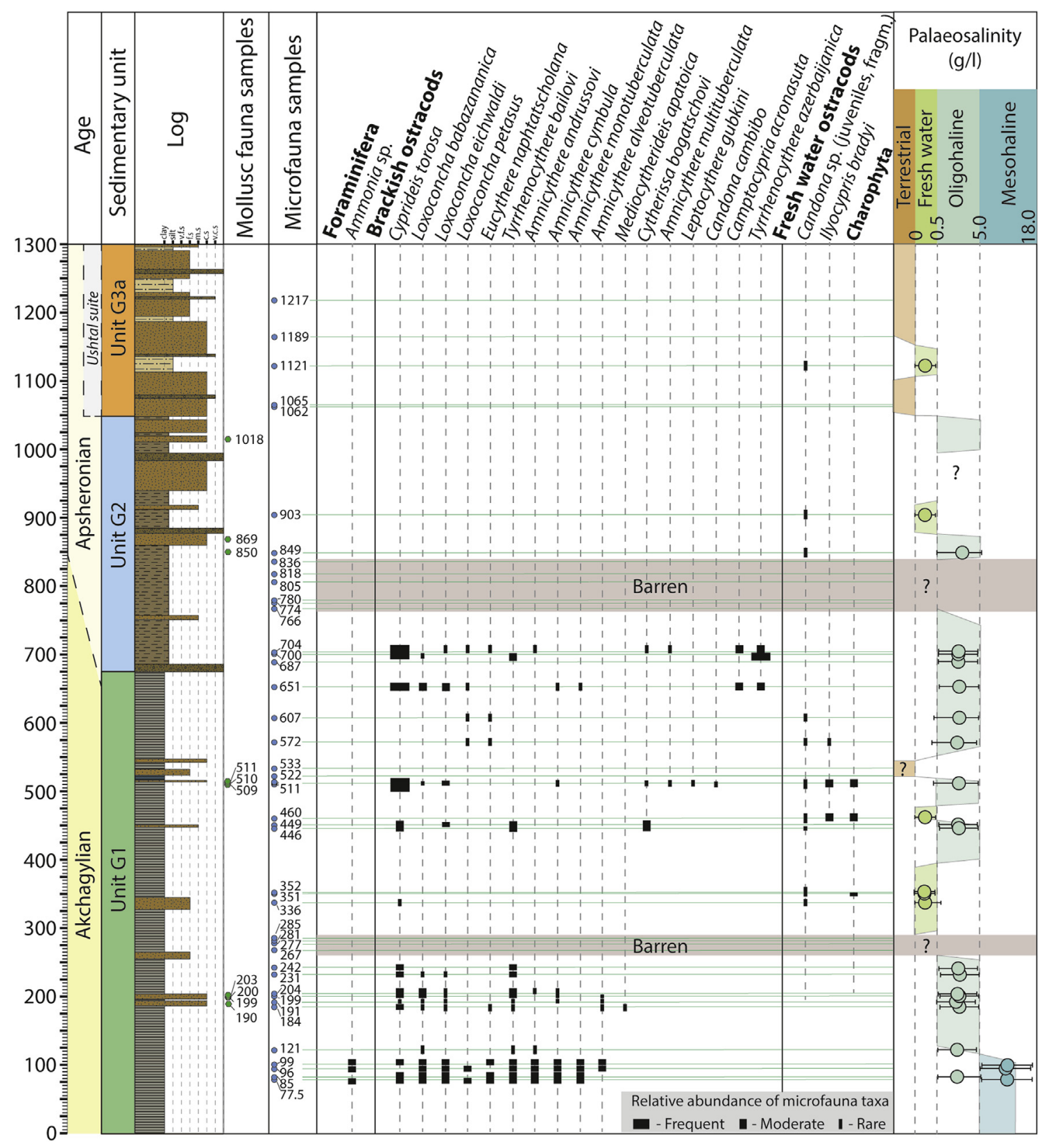

Fig. 3. Sedimentary log, paleontological sampling points, microfauna assemblages and paleosalinity estimation in the Goychay section.

and Candona sp. (fragments and juveniles) and charophytic gyrogonites. In the upper part of Unit G1, at $651 \mathrm{~m}$, abundant populations of Cyprideis torosa and Tyrrhenocythere azerbaijanica characterize levels with elevated (oligohaline) salinities. In addition, the anomalohaline species Amnicythere multituberculata, Leptocythere gubkini, Candona cambibo and Camptocypria acronasuta are present. This assemblage continues at the base of Unit G2 (700 m, $703.5 \mathrm{~m}$ ).

The major part of Unit G2 generally lacks microfauna. Exceptions are the short intervals between 849 and $903 \mathrm{~m}$ that contain rare and poorly preserved candonids, together with mollusc fauna suggesting freshwater to oligohaline environments.

Subunit G3a also lacks microfauna and only in one sample $(1121 \mathrm{~m})$ did we discover poorly preserved candonids that indicate fresh water environments (Fig. 3). Thereby, the micropaleontological record of the Goychay section displays a gradual transition from mesohaline to fresh water assemblages towards the top, which is in a good agreement with regressive trend observed in sedimentary facies.

The abundant ostracod fauna in the Goychay section resembles Akchagylian-Apsheronian ostracod assemblages described in other sections across the Kura Basin (Richards et al., 2018; Krijgsman et al., 2019; van Baak et al., 2019).

\subsubsection{Macrofauna (molluscs)}

Along the Goychay section, ten samples were analysed covering the interval 189-883 $\mathrm{m}$ (Table 1). These samples are from Unit G1 (samples GOY-M-01 - GOY-M-07) and from Unit G2 (samples GOYM-08 to GOY-M-10). The fluvial environment of subunit G3a contains very few molluscs, but some terrestrial gastropod species have been recorded there (Forte et al., 2013). In general, the studied mollusc assemblages seem to be in situ, marked by the presence of 
Table 1

Distribution of mollusc taxa in the Goychay section.

\begin{tabular}{|c|c|c|c|c|c|c|c|c|c|c|c|c|c|}
\hline \multirow{2}{*}{$\begin{array}{l}\text { Stratigraphic } \\
\text { level (m) }\end{array}$} & \multirow{2}{*}{$\begin{array}{l}\text { Mollusc } \\
\text { sample }\end{array}$} & \multicolumn{12}{|l|}{ Molluscs } \\
\hline & & $\begin{array}{l}\text { Adacna } \\
\text { sp. }\end{array}$ & $\begin{array}{l}\text { Apscheronia } \\
\text { propinqua }\end{array}$ & $\begin{array}{l}\text { Bithynia } \\
\text { sp. }\end{array}$ & $\begin{array}{l}\text { Caspia } \\
\text { apscheronica }\end{array}$ & $\begin{array}{l}\text { Celekenia } \\
\text { pachyostoma }\end{array}$ & $\begin{array}{l}\text { Clessiniola cf. } \\
\text { subvariabilis }\end{array}$ & $\begin{array}{l}\text { Corbicula } \\
\text { fluminalis }\end{array}$ & $\begin{array}{l}\text { Didacnomya } \\
\text { sp. }\end{array}$ & $\begin{array}{l}\text { Dreissena } \\
\text { carinatocurva }\end{array}$ & $\begin{array}{l}\text { Dreissena } \\
\text { polymorpha }\end{array}$ & $\begin{array}{l}\text { Dreissena } \\
\text { rostriformis }\end{array}$ & $\begin{array}{l}\text { Ecrobia cf. } \\
\text { grimmi }\end{array}$ \\
\hline 1018 & $\begin{array}{l}\text { GOY- } \\
\text { M-10 }\end{array}$ & 2 & & & 1 & & 1 & & 3 & & 1 & 1 & \\
\hline 868 & $\begin{array}{l}\text { GOY- } \\
\text { M-09 }\end{array}$ & & 1 & & 1 & & & & 2 & & & 3 & \\
\hline 849 & $\begin{array}{l}\text { GOY- } \\
\text { M-08 }\end{array}$ & & 2 & & 2 & 1 & & & & 1 & 2 & 3 & 1 \\
\hline 511 & $\begin{array}{l}\text { GOY- } \\
\text { M-07 }\end{array}$ & & & & & & & 2 & & & 2 & & \\
\hline 510 & $\begin{array}{l}\text { GOY- } \\
\text { M-06 }\end{array}$ & & & & 1 & & & 3 & & & 2 & & \\
\hline 509 & $\begin{array}{l}\text { GOY- } \\
\text { M-05 }\end{array}$ & & & 1 & & 1 & & & & & & & \\
\hline 203 & $\begin{array}{l}\text { GOY- } \\
\text { M-04 }\end{array}$ & & & & & 1 & & & & & 3 & & \\
\hline 200 & $\begin{array}{l}\text { GOY- } \\
\text { M-03 }\end{array}$ & & & & & 1 & & 1 & & & & 1 & \\
\hline 199 & $\begin{array}{l}\text { GOY- } \\
\text { M-02 }\end{array}$ & & & & & 1 & & & & & & 2 & 1 \\
\hline 190 & $\begin{array}{l}\text { GOY- } \\
\text { M-01 }\end{array}$ & & & & & 1 & & 1 & & & & 2 & \\
\hline Abundance & & & & & & & & & & & & & \\
\hline 1 & rare & \multirow{2}{*}{\multicolumn{12}{|c|}{$\begin{array}{l}1-10 \text { individuals } \\
11-30 \text { individuals }\end{array}$}} \\
\hline 2 & moderate & & & & & & & & & & & & \\
\hline 3 & frequent & \multicolumn{12}{|c|}{$>30$ individuals } \\
\hline
\end{tabular}

paired bivalves, and often show excellent preservation of gastropods and bivalves. In samples GOY-M-01 (189.5 m), GOY-M-06 (511.3 m), GOY-M-08 (849.3 m) and GOY-M-09 (868.6 m), rare indications of reworking are present (differences in coloration and abrasion). Samples GOY-M-02 (199 m), GOY-M-03 (200 m), GOY-M$04(203 \mathrm{~m})$ contain well preserved shells, nevertheless demonstrating features of a downslope transportation (irregular distribution in turbidite layers). Compaction (cracking) is common in several samples, as is some post-depositional dissolution.

Samples GOY-M-01 to GOY-M-04 are dominated by Laevicaspia, Turricaspia and Theodoxus gastropod species, and Dreissena and Corbicula bivalve species (Figs. 4 and 5). This assemblage resembles somewhat the modern oligohaline Caspian Sea faunas with the exception of Corbicula that is restricted to rivers today. Sample GOYM-02, dominated by Theodoxus, indicates vegetated seafloor at shallow depth. In sample GOY-M-05 (510.3 m) Lymnaeidae and Valvata frequently occur. It also contains a few Melanopsis individuals, Bithynia fragments and an operculum. Together with the abundant charophytes, we interpret this as a freshwater assemblage. Samples GOY-M-06 and GOY-M-07 are dominated by a mixture of Corbicula, dreissenids and abundant hydrobiids, likely representing freshwater to oligohaline conditions. In samples GOYM-08 to GOY-M-10, Lymnocardiinae species are common, as well as hydrobiids and some dreissenids. They all contain the Apsheronian gastropod Caspia apscheronica. In general, the upper three samples reflect more oligohaline to mesohaline shallow lake conditions.

Indicative Akchagylian mollusc groups such as Avimactra, Pirenella and endemic lymnocardiine genera (Andrusov, 1923; Kolesnikov, 1950) are absent in the Goychay section. In samples GOY-M-01 to GOY-M-07, we observe low oligohaline assemblages that are common in the Apsheronian (Table 1, Fig. 5). Occurring species are Laevicaspia subcaspia, Celekenia pachyostoma and thin elongated egg-shaped Caspia species (Caspia matura and C. apsheronica as illustrated in Kolesnikov, 1950). Starting from $849 \mathrm{~m}$ (samples GOY-M-08 to GOY-M-10) the indicative Apsheronian bivalve taxa Apscheronia propinqua s.l. and Monodacna sp. are present (Table 1, Fig. 4).

\subsubsection{Palaeomagnetic results}

The thermal demagnetization of samples from the Goychay section revealed two NRM components. The first is a low temperature component of normal polarity (LT_N) that becomes fully demagnetized at temperatures of $250-300{ }^{\circ} \mathrm{C}$ (Fig. 6A). Within a set of 84 samples from this section, $40 \%$ have a weak LT_N component that is fully demagnetized at $180^{\circ} \mathrm{C}$, whereas $30 \%$ lack this component. The mean direction of the LT_N component has parameters of $\mathrm{D}=5.9^{\circ}, \mathrm{I}=41.1^{\circ}, \mathrm{k}=10.8$, a95 $=6.6$ for $\mathrm{N}=47$ samples (Fig. 6B). The LT_N component is considered a present day overprint, even though the inclination values are aberrantly low. The magnetic field estimated values for the Goychay district are $\mathrm{D}=6.13^{\circ}, \mathrm{I}=59.4^{\circ}$ (https://www.ngdc.noaa.gov, May 2016).

The average inclination values of the LT_N component are $18^{\circ}$ lower than the expected present day field value. The equal area plot shows that all low temperature directions form two clouds - one around the current day magnetic overprint and the second widely dispersed. The isolation of the first cloud revealed parameters of $\mathrm{D}=8^{\circ}, \mathrm{I}=51.4^{\circ}, \mathrm{k}=46.7$, a95 $=4.5$ for $\mathrm{N}=23$ samples (Fig. $6 \mathrm{C}$ ). These values are closer to the parameters of the present day magnetic field in the Goychay district and may be considered as viscous present-day overprints. The second group of random directions is possibly represented by another viscous remanent magnetization.

The second component is further subdivided into two groups: a medium temperature component (MT_R) with a demagnetization temperature range $300^{\circ}-400^{\circ} \mathrm{C}$ (Fig. 6D) and a high temperature component (HT_N, HT_R) with a maximum demagnetization temperature up to $680^{\circ} \mathrm{C}$ (Fig. $6 \mathrm{G}$ and $\mathrm{H}$ ). Both (medium and high) decay towards the origin. Samples with a MT component constitute about $20 \%$ of all measured samples and are characterized by a reversed signal. The mean direction of the MT_R component has parameters $\mathrm{D}=194.7^{\circ}, \mathrm{I}=-52.1^{\circ}, \mathrm{k}=29.2$, a95 $=8.2$ for $\mathrm{N}=12$ samples in tectonic coordinates (Fig. 6E). Thermomagnetic runs of the sample GO1 show an abrupt magnetization decrease down to $340-350^{\circ} \mathrm{C}$ with irreversible magnetization loss while cooling is applied (Fig. 6F). This signature is typical for greigite (Vasiliev et al., 2008). After the drop, a small peak forms between 400 and $580^{\circ} \mathrm{C}$ (Fig. 6F) that is characteristic for presence of pyrite (e.g. Palcu et al., 2019). Therefore, in the basal part of the Goychay section, the iron 


\begin{tabular}{|c|c|c|c|c|c|c|c|c|c|c|c|c|c|c|c|}
\hline \multicolumn{13}{|l|}{ Molluscs } & \multicolumn{3}{|l|}{ Paleosalinity } \\
\hline \multirow[t]{6}{*}{$\begin{array}{l}\text { Gyraulus } \\
\text { sp. }\end{array}$} & $\begin{array}{l}\text { Laevicaspia } \\
\text { sp. }\end{array}$ & $\begin{array}{l}\text { Laevicaspia } \\
\text { sp nova }\end{array}$ & $\begin{array}{l}\text { Laevicaspia } \\
\text { subcaspia }\end{array}$ & $\begin{array}{l}\text { Lymnaea } \\
\text { sp. }\end{array}$ & $\begin{array}{l}\text { Melanopsis } \\
\text { beregoni }\end{array}$ & $\begin{array}{l}\text { Monodacna } \\
\text { sp. }\end{array}$ & Pseudocatillus sp. & $\begin{array}{l}\text { Streptocerella } \\
\text { sp. }\end{array}$ & $\begin{array}{l}\text { Theodoxus } \\
\text { pallasi }\end{array}$ & $\begin{array}{l}\text { Turricaspia } \\
\text { sp. }\end{array}$ & $\begin{array}{l}\text { Valvata } \\
\text { sp. }\end{array}$ & $\begin{array}{l}\text { Charophyta } \\
\text { gyrogonites }\end{array}$ & $\begin{array}{l}\text { Fresh } \\
\text { water } \\
(0-0.5 \mathrm{ps} \mu)\end{array}$ & $\begin{array}{l}\text { Oligohaline } \\
(0.5-5 \mathrm{ps} \mu)\end{array}$ & $\begin{array}{l}\text { Mesohaline } \\
(5-18 \mathrm{ps} \mu)\end{array}$ \\
\hline & & & & & & & & & & & & & & $\mathrm{X}$ & $X$ \\
\hline & 3 & 1 & 3 & & & 1 & & & 1 & & & & & $\mathrm{X}$ & $\mathrm{X}$ \\
\hline & 2 & 3 & 2 & & 2 & & 2 & & 2 & & & & $\mathrm{X}$ & $\mathrm{X}$ & $\mathrm{X}$ \\
\hline & 2 & & 2 & & & & & & & & & & $\mathrm{X}$ & $\mathrm{X}$ & $?$ \\
\hline & 2 & & 2 & & & & & 1 & 1 & & 2 & & $\mathrm{X}$ & $\mathrm{X}$ & \\
\hline & & & & 2 & 1 & & & & & & 2 & 3 & $X$ & & \\
\hline \multirow[t]{4}{*}{1} & & & 3 & & & & & & 3 & & & & & $X$ & \\
\hline & 3 & & 3 & & & & & & & 3 & & & & $X$ & ? \\
\hline & & & & & & & & & 3 & 2 & & & & $X$ & \\
\hline & 2 & & 3 & & & & & & & 2 & & & & $\mathrm{X}$ & $?$ \\
\hline
\end{tabular}

sulphide greigite is considered the main magnetic carrier.

The mean direction of the high temperature reversed group (HT_R) has parameters of $\mathrm{D}=187.9^{\circ}, \mathrm{I}=-49^{\circ}, \mathrm{k}=17.2$, a95 $=5.3$ for $\mathrm{N}=44$ samples in tectonic coordinates, whereas the normal group (HT_N) mean direction is $\mathrm{D}=2.9^{\circ}, \mathrm{I}=41.7^{\circ}, \mathrm{k}=11.7$, a95 $=12.1$ for $\mathrm{N}=14$ samples (Fig. $6 \mathrm{I}$ and $\mathrm{J}$ ). Thermomagnetic runs for samples G039 and G076 demonstrate a gradual decrease of magnetization down to $580^{\circ} \mathrm{C}$ (Fig. $6 \mathrm{~K}, \mathrm{~L}$ ). This signature is characteristic for the iron oxide - magnetite - the main magnetic carrier in these samples. Some samples demonstrate a stable signal that continues decaying towards the origin until $670-680^{\circ} \mathrm{C}$ (Fig. 6H). They turn red-coloured while being heated. We interpret this magnetic carrier as hematite, even though it is not expressed on the thermomagnetic curves (Fig. 6M), due to weaker remanence

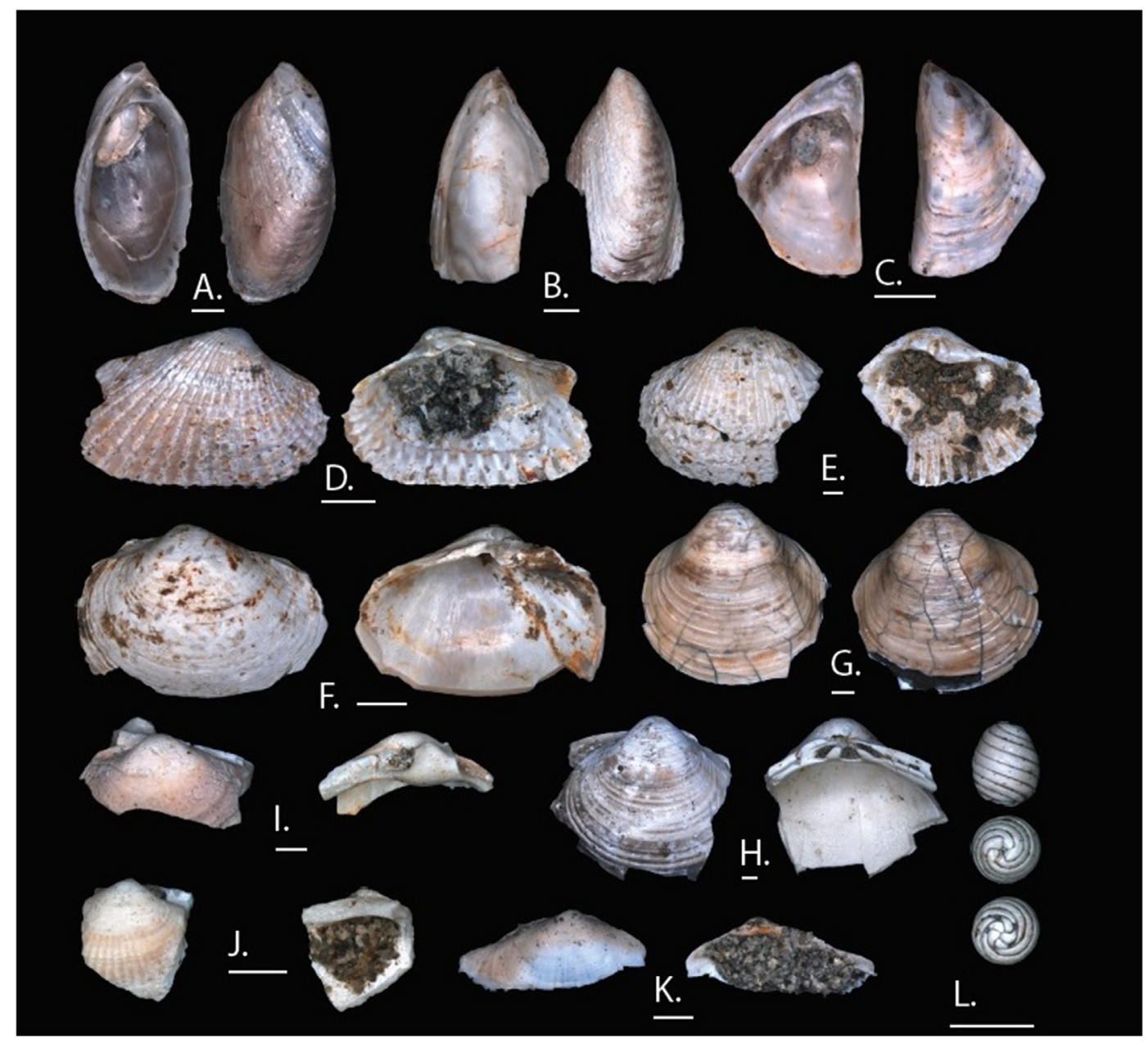

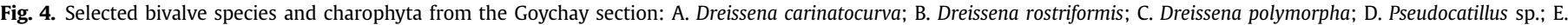

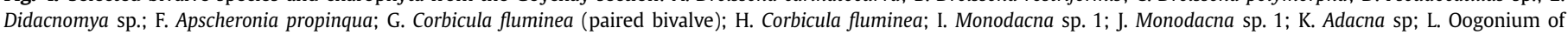
charophyta. (Scale bars $1 \mathrm{~mm}$ ). 


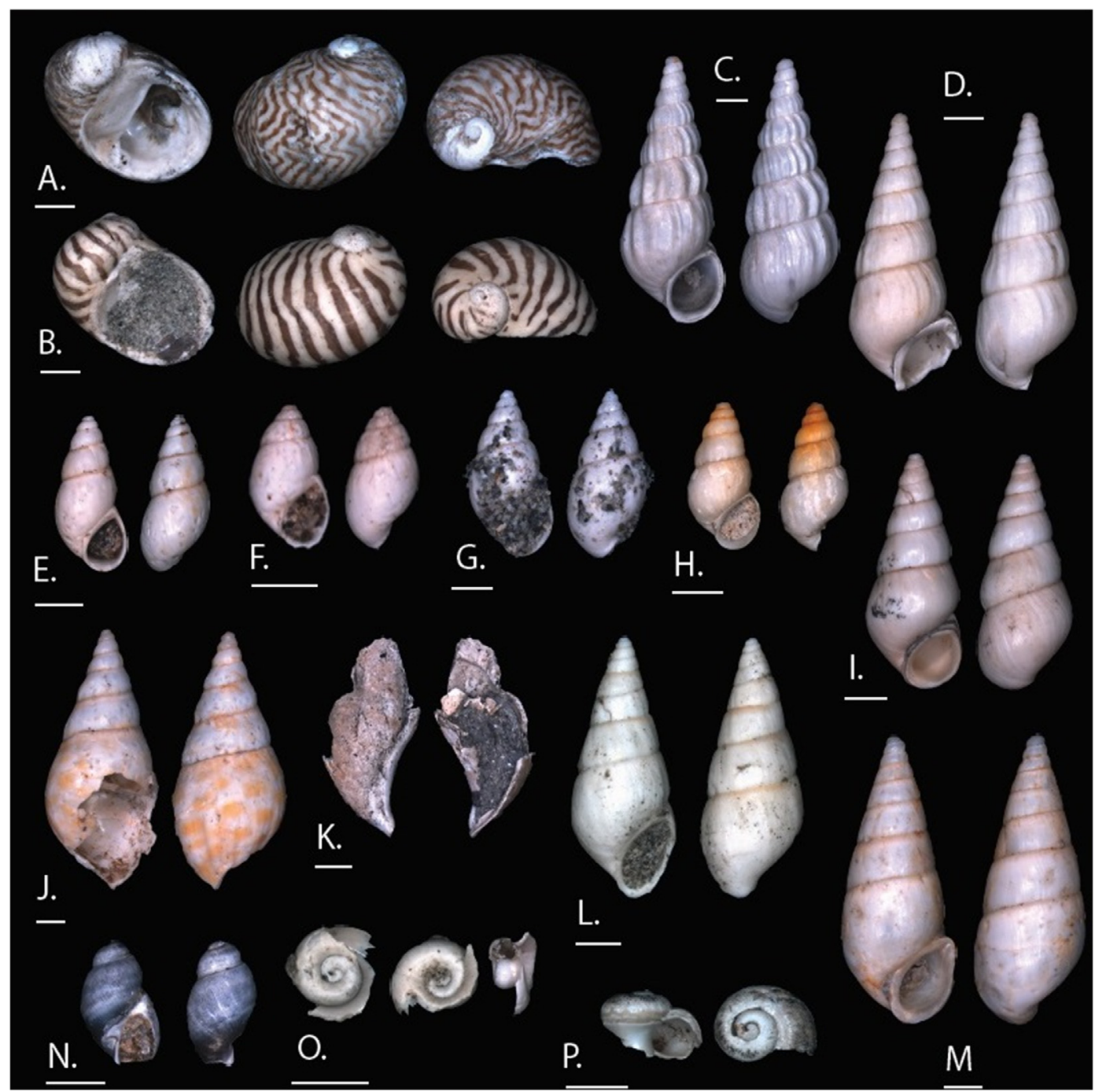

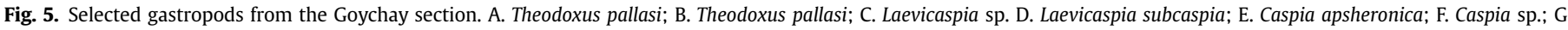

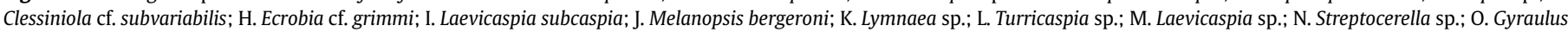
sp.; P. Valvata sp. (Scale bars $1 \mathrm{~mm}$ ).

of hematite compare to magnetite remanence (Dunlop and Ozdemir, 1997). The similarity of the HT_R and MT_R directions indicates that they represent the same magnetic direction. We combine the reversed direction of the two groups under the name "all reversed" (Fig. 6N). The reversal test of McFadden and McElhinny (1990) for the group MT_R and HT_R (all reversed) and HT_N is positive (Fig. 60). Therefore, the second magnetic component (MT_R, HT_R, HT_N) is interpreted as being characteristic for the sedimentation age (ChRM).

The Goychay section is dominated by a reversed polarity (reversed zones R1, R2, R3 and R4) with two relatively short normal polarity intervals in the lower (N1: 612-638 m) and upper part (N3: 2091-2112 m) and one long normal interval in the middle (N2: 889-1148 m) (Fig. 7). A bulk magnetic susceptibility analysis performed for all measured samples shows highly fluctuating values in the lower fine-grained units. After $1400 \mathrm{~m}$, the values stabilize at about 1.00E-07 (Fig. 7).

\subsection{Hajigabul section}

\subsubsection{Lithological description}

The sedimentary succession of the Hajigabul section can be divided into four main sedimentary units (Fig. 2B). Unit H1 $(0-205 \mathrm{~m})$ is mostly composed of brownish fine to coarse sandstones, deposited in centimetre-to meter-thick erosive layers. Sandstone beds display normal grading, centimetre-to decimetrescale sigmoidal cross-stratification, centimetre-to decimetre-scale trough cross-stratification and millimetre-scale horizontal laminations. Sedimentary structures are typically separated by finer grained sandstone or by dark-grey organic-rich clay partings. Sandstone layers alternate with yellowish-brown and reddish claystones and siltstones. These finer deposits contain millimetreto centimetre-scale organic material fragments and contain some centimetre-scale vertical burrows. Claystones occasionally display slickensides, centimetre-scale vertical rootlets and contain some rare flat terrestrial gastropod shells. The interval below the boundary between Unit $\mathrm{H} 1$ and Unit $\mathrm{H} 2$ displays several ash layers. Unit $\mathrm{H} 1$ is interpreted to be deposited in fluvial environments. The organic-rich fine sediments were deposited out of suspension on floodplain and later pedogenically modified. Thereby, Unit H1 was formed in terrestrial, floodplain and fluvial depositional environments.

The base of Unit H2 (205-457 m) is marked by the abrupt transition to dark-grey mudstones that overly sandstones from the 


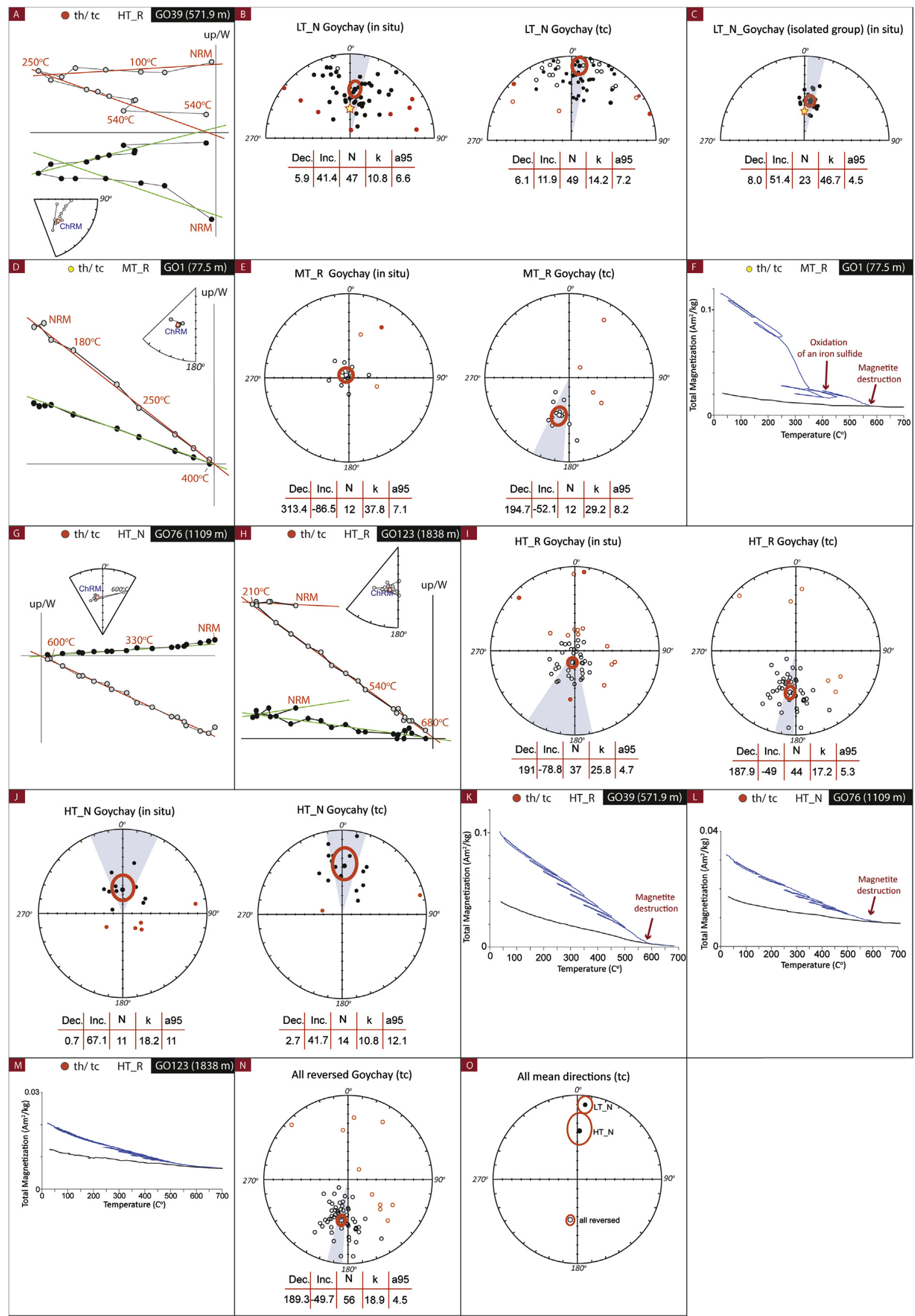

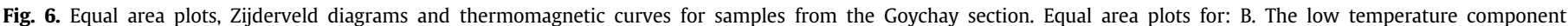

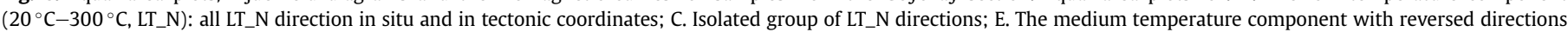

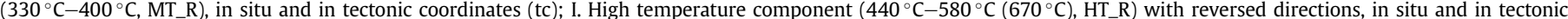

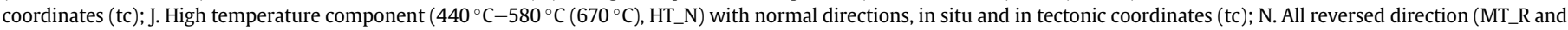

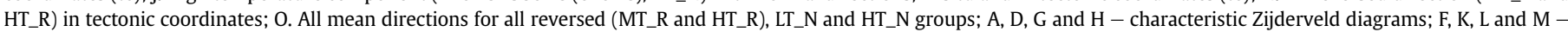
characteristic thermomagnetic runs for various samples. 


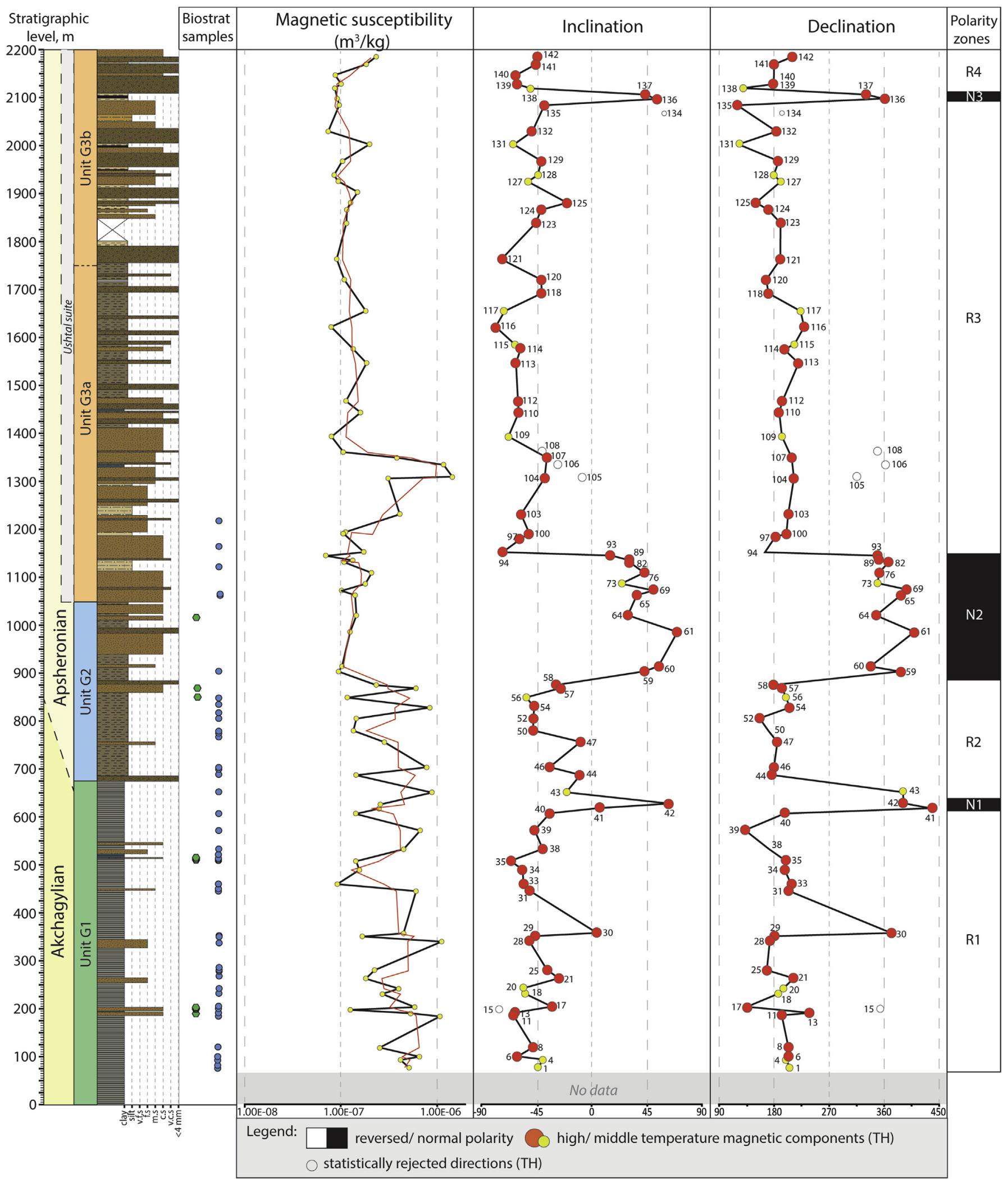

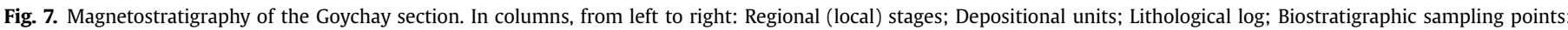

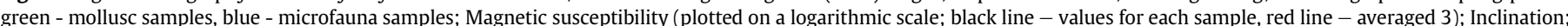

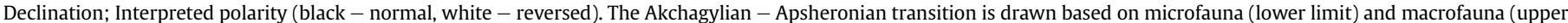
limit). (For interpretation of the references to colour in this figure legend, the reader is referred to the Web version of this article.) 
previous Unit H1 (Fig. 2B). These fine-grained deposits contain millimetre-scale horizontal lamination, made of brownish grey mudstones and siltstones. Some anomalohaline molluscs are found in these deposits including paired lymnocardiine bivalves. Claydominated sediments recorded in Unit $\mathrm{H} 2$ were deposited out of suspension in distal open-water environments, which implies a major transgressive phase following Unit $\mathrm{H} 1$.

Unit H3 (457-1614 $\mathrm{m}$ ) records an alternation between fine and coarse sediments. The previously described dark-grey mudstones are repetitively intercalated with fine to coarse-grained brownish sandstones, and with greenish and reddish claystones (Fig. 2B). The sandstones are deposited in centimetre-to decametre-thick layers. They display normal grading, centimetre-to meter-scale sigmoidal cross-stratification, centimetre-to decimetre-scale trough crossstratification, millimetre-scale horizontal laminations, centimetreto decimetre-scale scours and centimetre-to decimetre-scale hummocky cross-stratification. These sandstones are interpreted to be deposited in nearshore environments. Towards the top of Unit $\mathrm{H} 3$, decimetre-scale low-angle cross-stratification and wavybedding become common, suggesting lateral move towards coastal depositional environments. Unit $\mathrm{H} 3$ also contains some centimetre-to decimetre-thick layers of greenish and reddish claystones. These claystones display slickenslides and contain plant debris, fresh water molluscs and centimetre-scale vertical burrows. We interpret this claystones to be formed in lagoonal and terrestrial environments. Overall, Unit H3 shows frequent oscillations between distal claystones deposited in open-water environments proximal sandstones deposited in nearshore and coastal environments and greenish and reddish claystones deposited in lagoons and terrestrial settings. Unit $\mathrm{H} 3$ represents a regression phase following the Unit $\mathrm{H} 2$, and recording repetitive lake-level oscillations.

Unit H4 (1614-2050 m) consists of yellowish-grey claystones and siltstones. Towards the top, they are frequently interbedded with brownish siltstones to fine sandstones, deposited in millimetre-to decimetre-thick layers (Fig. 2B). These sandstones present centimetre-scale sigmoidal cross-stratification, centimetre-scale trough cross-stratification, millimetre-scale horizontal lamination and centimetre-scale scours. The claystone- and siltstone-dominated Unit $\mathrm{H} 4$ is interpreted to be deposited out of suspension in nearshore environments, repeatedly disrupted by small, density underflow currents in the upper part of this interval. The boundary between Units H3 and H4 denotes a major transgressive event.

\subsubsection{Microfauna (ostracods and foraminifera)}

Throughout the Hajigabul section, several assemblages have been identified, representing frequent variations between freshwater, oligohaline and mesohaline environments (Fig. 8). Unit H1 (at $110 \mathrm{~m}$ ) contains only freshwater ostracods. Most common taxa are represented by cyprinid ostracod species such as Candona elongata, Candona sp. (the majority poorly preserved or in juvenile stages), Eucypris sp., Cypris subglobosa, Ilyocypris bradyi and Darwinula stevensoni. Similar assemblages have previously been reported from fine grained, lacustrine intercalations within the Productive Series of the South Caspian Basin (van Baak et al., 2013).

The base of Unit H2 (211 m-453 m) contains an oligohaline assemblage replacing the previous freshwater one (Fig. 8). Ostracods in this interval are moderately abundant and taxonomically diverse. Most common taxa include Limnocythere alveolata, L. luculenta, Eucythere naphtatscholana, loxoconchid species represented by Loxoconcha eichwaldi, L. petasa and L. babazananica as well as numerous leptocytherids represented by Leptocythere gubkini, Amnicythere ex. gr. andrussovi, A. nata, A. multituberculata, A. cymbula and Euxinocythere praebosqueti. Two candonid ostracod species are observed: $C$. candida and Camptocypria acronasuta. Less frequently occurring taxa are Mediocytherideis apatoica, Tyrrhenocythere bailovi and Cytherissa bogatschovi. The faunal composition within unit $\mathrm{H} 2$ is consistent and only shows a barren interval between the stratigraphic levels $427 \mathrm{~m}-543 \mathrm{~m}$. The disappearance may suggest the presence of poorly oxygenated water.

Unit H3 (453 m-1614 m) contains more diverse ostracod assemblages. At $543 \mathrm{~m}$, a re-established microfauna resembles the same groups as those before the barren zone. Among them are rare ostracods of Eucythere naphtatscholana, Cytherissa bogatschovi and Camptocypria acronasuta (Fig. 8). In the interval $616 \mathrm{~m}-755 \mathrm{~m}$, ostracod fauna demonstrates quantitative increase of previously presented groups as well as two new taxa - Tyrrhenocythere azerbaijanica and Cyprideis torosa occur. Moreover, this interval is rich in foraminifera - Ammonia, Cibicides and Cassidulina that points at a higher, mesohaline level of salinity (Fig. 8). After this interval with higher salinity, disappearance of foraminifera suggests a reduction of salinity, and ostracod fauna consists of oligohaline assemblages alternating with a few freshwater intervals (755-1701 m). Here, oligohaline assemblages include Cyprideis torosa, Tyrrhenocythere azerbaijanica, and Xestoleberis chanakovi.

At $1110 \mathrm{~m}$, there is a level rich in foraminifera like Ammonia sp., Cassidulina sp. and Porosononion sp. It might indicate a short salinity incursion, caused by an influx of marine water. Between 1465 and $1490 \mathrm{~m}$, a remarkable occurrence of seven new taxa in addition to previous assemblage was revealed: Loxoconcha rugosa, L. lepida, L. endocarpus ?, Candona schweyeri, Tyrrhenocythere donetziensis, Bakunella dorsoarcuata, Cypria sp. (Fig. 8). Thereby, the taxonomic content of the microfauna assemblage is remarkably enriched within Unit $\mathrm{H} 3$.

In Unit H4, at 1701-1719 m, another salinity incursion is indicated by the presence of euryhaline foraminifera like Ammonia and Cibicides spp. (Fig. 8). Dominant ostracod taxa are Eucythere naphtatscholana, Cytherissa bogatschovi, Amnicythere nata, A. caspia, A. camelii, A. cymbula as well as numerous loxoconchids including Loxoconcha eichwaldi, L. petasa, L. endocarpus, L. lepida, L. pulchella, L. gibboides. Many ostracod species show transitional morphotypes, hinting at rapid and frequent environmental changes. This suggests shallow anomalohaline/oligohaline lake environments with interrupting lagoon/littoral levels.

A further salinity incursion (1842 $\mathrm{m}$ ) is marked by an abundance of euryhaline foraminifera with Ammonia sp., as well as Cassidulina sp., and Porosononion sp. (Fig. 8). The ostracod assemblage here is similar to the one prevailing in the lower part of Unit $\mathrm{H} 4$ and shows strong resemblance to the recent living fauna in the Caspian Sea.

\subsubsection{Macrofauna (molluscs)}

Unit $\mathrm{H} 2$ contains very rare, partially dissolved shells and imprints of cardiids and Dreissena rostriformis and occasional finds of the gastropod Pirenella caspia (Andrusov, 1902) (Fig. 9j). The bivalves are often paired, or with valves in close proximity, implying in situ preservation with some burrowing activity. Bivalves found in Unit H2 imply a very low energy muddy saline lake floor assemblage. Four Cardiidae species were observed between $395 \mathrm{~m}$ and $428 \mathrm{~m}$, and we have difficulties to establish their identities. Cardiidae sp. A (Fig. 9a) is a small (about $1.2 \mathrm{~cm}$ wide) flat, thin-shelled species with very broad and very low flat ribs separated by almost obsolete grooves. The general outline resembles the modern Adacna vitrea but further study of the hinge will be required to assess whether Cardiidae sp. A can be attributed to that genus. Cardiidae sp. B (Fig. 9b-d) has an intermediate-sized ( $>2 \mathrm{~cm}$ wide) shell with a sub-rounded outline. The shells' ribbing is very specific: Three very distinct ribs on the posterior half of the disk give way to three low and clearly imbricate ribs on the anterior side. The 


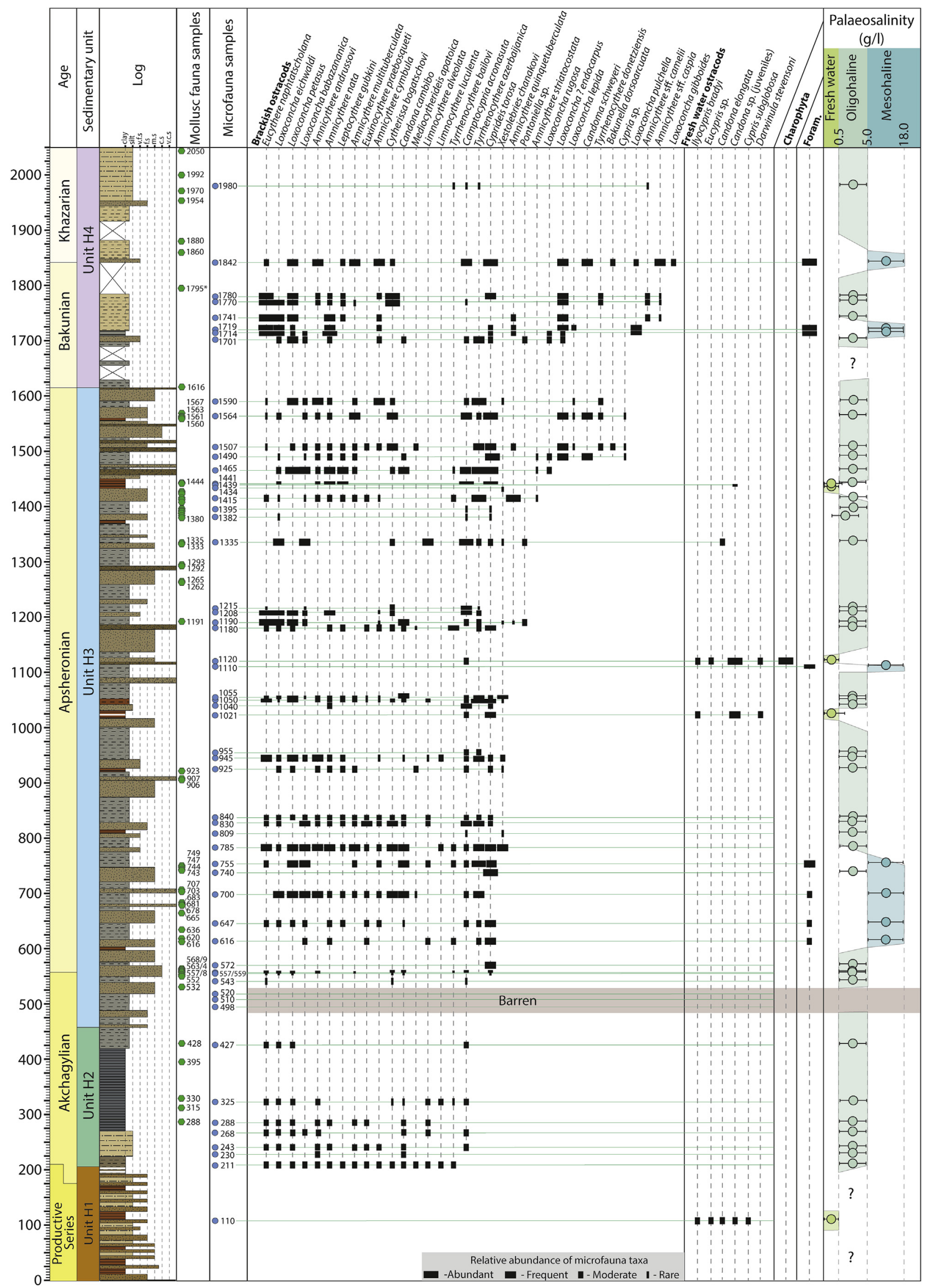

Fig. 8. Sedimentary log, paleontological sampling points, microfauna assemblages and paleosalinity estimation in the Hajigabul section. 


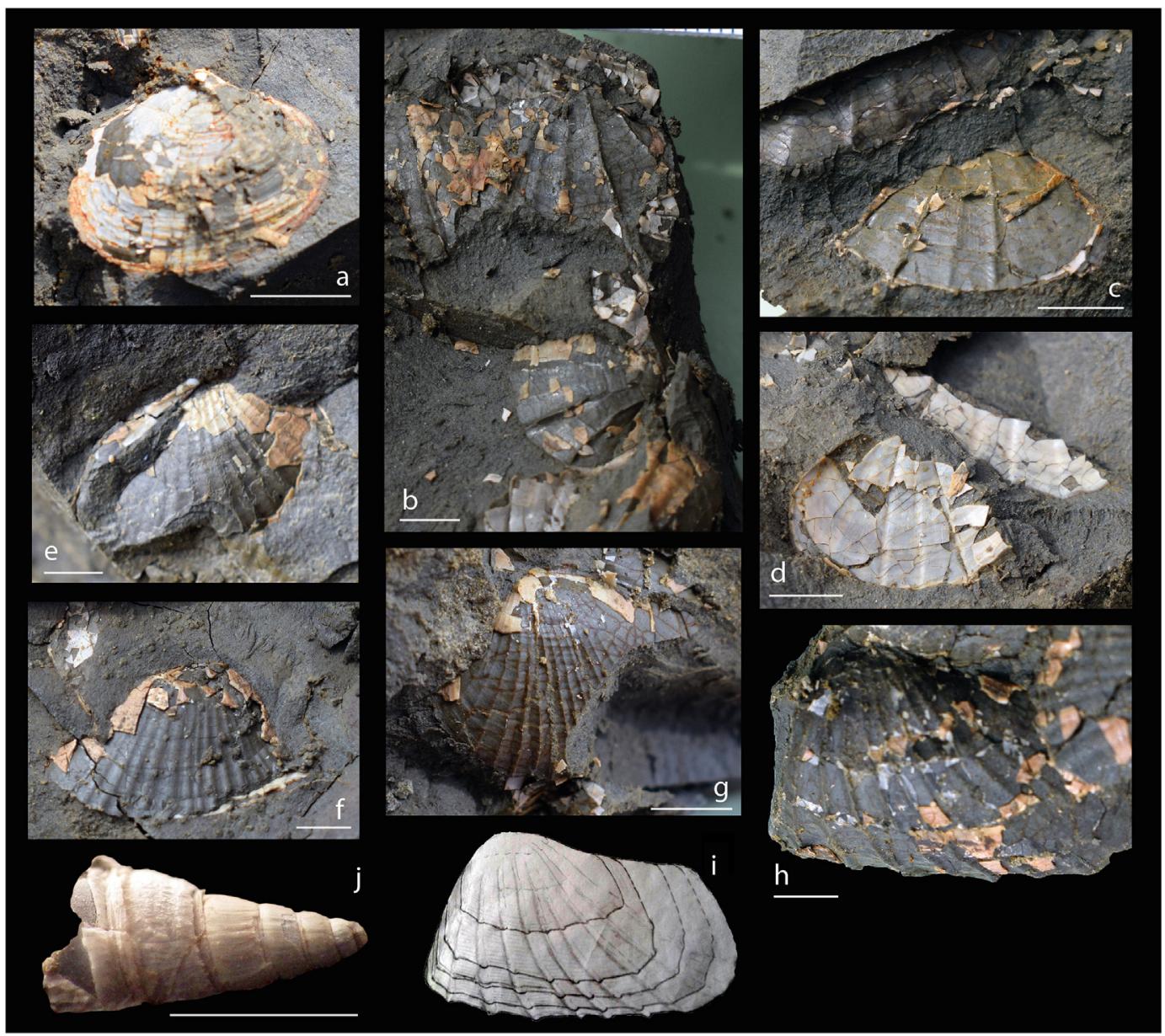

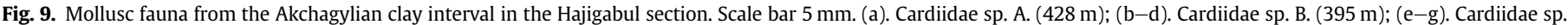
(395 m); (h, i). Avicardium nikitini (395 m); ((i) is a reconstruction); (j) Pirenella caspia (288 m).

pointed ribs do resemble those of Parapsheronia raricostata s.l. from the Apsheronian, but the resemblance is superficial. No imbricated anterior ribs are known for Parapsheronia and the erect posterior ribs in Cardiidae sp. B are much thinner with wide, almost concave, interspaces. The posterior margin of the former species is smooth. Cardiidae spec. B has some commonalities with the Akchagylian species Avicardium radiiferum (see Danukalova, 1996, pl. 14, Figs. 1-4) yet the new material appears to have a rhomboid shape and not an elongated shape as in the latter. Cardiidae sp. C (Fig. 9e$\mathrm{g}$ ) is a very thin-shelled, slightly convex, sub-rounded, sub-triangular to sub-rectangular species wearing approximately 20 thin erect posterior ribs at more or less equal distances with flat broad interspaces. In some specimens, the ribbing becomes more irregular towards the posterior margin. Cardiidae sp. $\mathrm{C}$ has a similar shape as some of the Miricardium caracutum (see Danukalova, 1996, pl. 12, Figs. 1-10) but that shape-variable species has lesser ribs. Several imprints are attributed to Avicardium nikitinum (Andrusov, 1902) (Fig. 9h and I, see for comparison Danukalova, 1996, pl. 13, Fig. 4)). The species is relatively large $(3 \mathrm{~cm})$, convex and irregular sub-quadrangular. The anterior margin appears truncated, the posterior margin is greatly expanded. Approximately ten welldeveloped ribs occur with wide flat interspaces about three times as wide. The shell has a Pholadomya outline. The outline also resembles the Apsheronian Adacna(?) andrusovi as illustrated in Kolesnikov (1950) (table 26, Figs. 4-6), yet the latter species appears to have strong ribbing throughout the shell whereas ribbing in our material clearly fades towards the posterior end. Attribution of this mollusc fauna to the Akchagylian is tentative and open to further scrutiny. The presence of Pirenella caspia and Avicardium nikitini are the best indicators (Fig. 9i, j). The cardiids of Cardiidae sp. A, B and C in the section likely represent a deep-water fauna that requires further taxonomic elaboration.

In Unit 3, new oligo-mesohaline communities with Dreissena rostriformis, Monodacna sp., and Apscheronia propinqua s.l. occur (Table 2). Besides that, fresh water intervals dominated by Unio are also present. We correlate unit $\mathrm{H} 3$ to the Apsheronian. Two other smooth Apscheronia species have been reported before (A. brevior and $A$. preextensa). The distinction in species is mainly based on the height/width ratios of adult specimens. In the studied material, however, mainly juvenile and broken specimens were found and we lumped these into Apscheronia propinqua s.l. Other occurrences, such as Hyrcania, Didacnomya and Monodacna spp. confirm the Apsheronian age.

Unit H4 contains a number of faunal levels that yield Middle Pleistocene faunas (Table 3). The section itself has been documented along a small river valley parallel to the main one (Section B). Here we report on the age-diagnostic Didacna species (Fig. 10). Sample 18DS09 $(1795 \mathrm{~m})$ was an indurated claystone layer with cracked, partially dissolved Didacna, which were paired but could not be sampled. Here, we identified in the field an assemblage containing Didacna corpulenta, D. parvula, D. cf. carditoides and D. alibajramlinica. Higher in the section, at $1860 \mathrm{~m}$, we found 


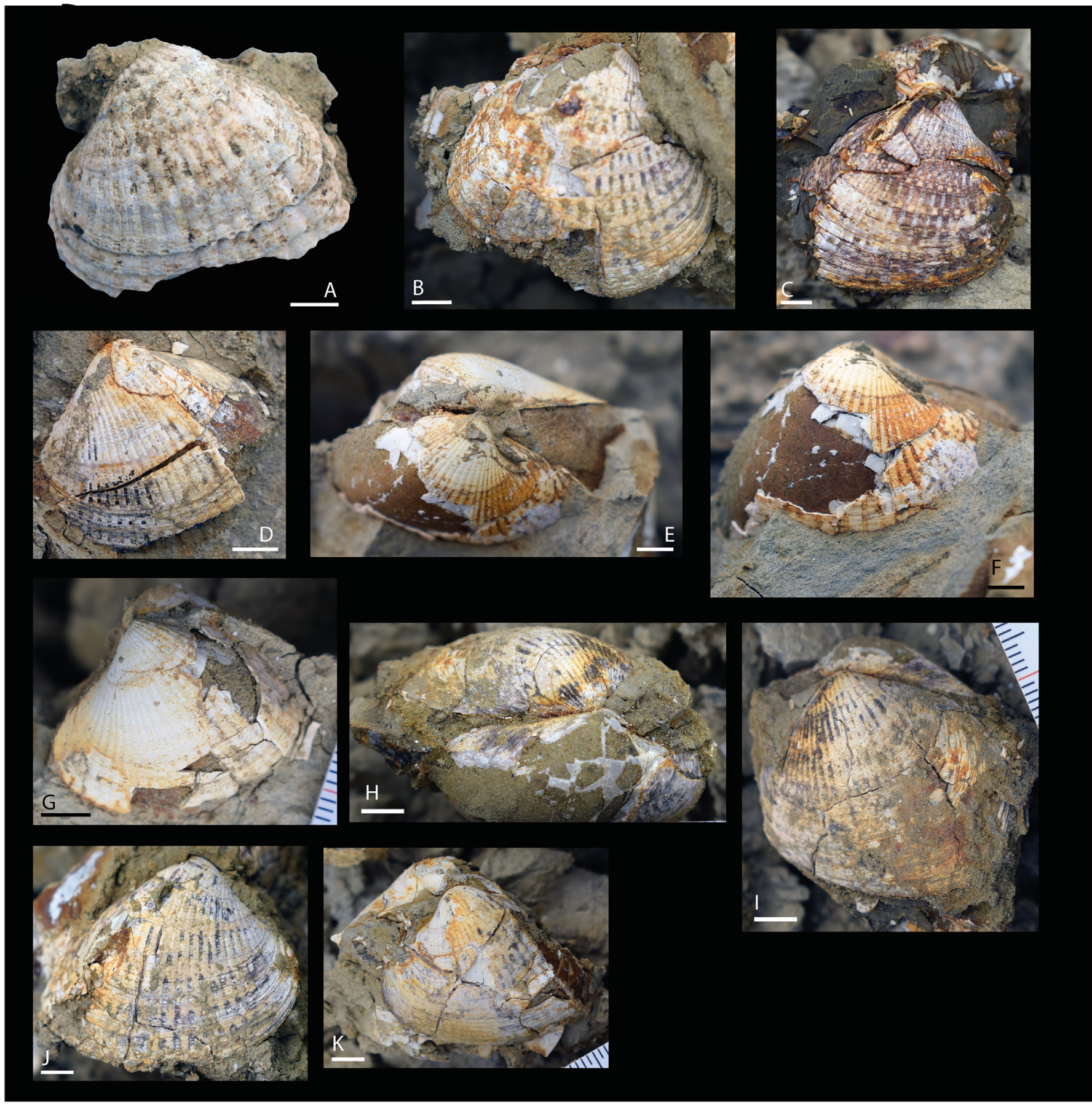

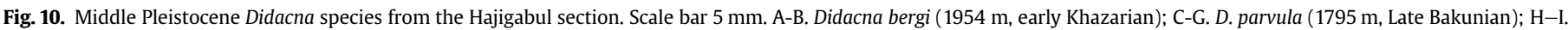
D. cf carditoides (1795 m, Late Bakunian); J-K. Didacna sp (1795 m, Late Bakunian).

Didacna eulachia, D. charamica, D. subpyramidata and D. trigonula. In the upper part of Unit H4, at 1954 m sediments contain Didacna bergi, D. hospes, $D$. cf. gurganica, D. trigonula, D. eulachia and $D$. subcatillus and Corbicula cf. fluminalis.

\subsubsection{Paleomagnetism}

Demagnetization of 181 samples from the Hajigabul section revealed two NRM components: a low-temperature (LT_N) and high (medium) temperature component that is directed towards the origin of the Zijderveld diagram (MT, HT). The low temperature component typically demagnetizes between $180^{\circ}$ and $250^{\circ} \mathrm{C}$
(Fig. 11A). The mean direction of this component has values of $\mathrm{D}=359.3^{\circ}, \mathrm{I}=54^{\circ}, \mathrm{k}=27, \mathrm{a} 95=2.6$ for $\mathrm{N}=116$ samples in geographic coordinates (Fig. 11B). The present-day magnetic field parameters for the Hajigabul section are $\mathrm{D}=6.07^{\circ}, \mathrm{I}=59.26^{\circ}$ (https://www.ngdc.noaa.gov, April 2017). We interpret the low temperature component as present-day field overprint. The second component consists of two sub-groups: medium temperature (MT_R, MT_N) and high temperature (HT_N, HT_R) components. The medium temperature component fully demagnetizes at $400{ }^{\circ} \mathrm{C}$ and represents an iron sulphide, most likely greigite. The high temperature component is fully demagnetized at $580^{\circ} \mathrm{C}$ (Fig. 11C). 
Table 2

Distribution of Akchagylian and Apsheronian mollusc taxa in the Hajigabul section.

\begin{tabular}{|c|c|c|c|c|c|c|c|c|c|c|c|c|c|c|c|}
\hline $\begin{array}{l}\text { Stratigraphic } \\
\text { level, m }\end{array}$ & $\begin{array}{l}\text { Pirenella } \\
\text { caspia }\end{array}$ & $\begin{array}{l}\text { Avicardium } \\
\text { nikitini }\end{array}$ & $\begin{array}{l}\text { Cardiidae } \\
\text { sp. }\end{array}$ & $\begin{array}{l}\text { Fagotia } \\
\text { sp. }\end{array}$ & $\begin{array}{l}\text { Theodoxus } \\
\text { sp. }\end{array}$ & $\begin{array}{l}\text { Hydrobiidae } \\
\text { sp. }\end{array}$ & $\begin{array}{l}\text { Corbicula } \\
\text { fluminalis s.l. }\end{array}$ & $\begin{array}{l}\text { Unio } \\
\text { sp. s.l. }\end{array}$ & $\begin{array}{l}\text { Apscheronia } \\
\text { propinqua s.l. }\end{array}$ & $\begin{array}{l}\text { Parapsheronia. } \\
\text { raricostata s.l. }\end{array}$ & $\begin{array}{l}\text { Hyrcania/ } \\
\text { Didacnomya spp. }\end{array}$ & $\begin{array}{l}\text { Monodacna } \\
\text { sp. }\end{array}$ & $\begin{array}{l}\text { Didacna } \\
\text { indet. }\end{array}$ & $\begin{array}{l}\text { Dreissena } \\
\text { rostriformis s.l. }\end{array}$ & $\begin{array}{l}\text { Dreissena } \\
\text { caspia }\end{array}$ \\
\hline 1616 & & & & & & & & & & & & & & $\mathbf{X}$ & \\
\hline 1567 & & & & & & $\mathbf{X}$ & & & $?$ & & $\mathbf{x}$ & & & $\mathbf{x}$ & \\
\hline 1563 & & & & & & & & & & & & & & $\mathbf{X}$ & \\
\hline 1561 & & & & & & $\mathbf{X}$ & & & $\mathbf{X}$ & & 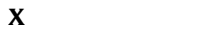 & $\mathbf{X}$ & $\mathbf{X}$ & $\mathbf{X}$ & \\
\hline 1560 & & & & & & & & & $\mathbf{X}$ & & $\mathbf{x}$ & $\mathbf{X}$ & & $\mathbf{X}$ & $x$ \\
\hline 1444 & & & & & & & & & & & $?$ & & $?$ & $\mathbf{X}$ & \\
\hline 1442 & & & & & & & & & $\mathbf{X}$ & & & $X$ & & & \\
\hline 1427 & & & & & & & $\mathbf{X}$ & $\mathbf{x}$ & & & & & & & \\
\hline 1425 & & & & & & $\mathbf{X}$ & & & & & & & & $\mathbf{X}$ & \\
\hline 1415 & & & & & & & & & $\mathbf{X}$ & & $\mathbf{X}$ & $X$ & $?$ & $\mathbf{x}$ & \\
\hline 1407 & & & & & & & & & & & $\mathbf{x}$ & $\mathbf{X}$ & & $\mathbf{x}$ & \\
\hline 1398 & & & & & & & & & & & $\mathbf{x}$ & $\mathbf{X}$ & & $\mathbf{X}$ & \\
\hline 1390 & & & & & & & & $\mathbf{X}$ & & & & & & & \\
\hline 1383 & & & & & & & & $\mathbf{X}$ & & & & & & & \\
\hline 1380 & & & & & & & & $\mathrm{X}$ & & & & & & & \\
\hline 1335 & & & & & & & & & $\mathbf{X}$ & & $?$ & $\mathbf{X}$ & $?$ & & \\
\hline 1333 & & & & & & & & & & & $\mathbf{X}$ & $\mathbf{x}$ & & & \\
\hline 1293 & & & & & & & & & & & $x$ & $\mathbf{X}$ & & & \\
\hline 1292 & & & & & & & & & & & & & & $\mathbf{X}$ & \\
\hline 1265 & & & & & & & & & & & & $\mathbf{x}$ & & & \\
\hline 1262 & & & & & & & & & & & & & & $\mathbf{X}$ & \\
\hline 1191 & & & & & $\mathbf{X}$ & & & & & & $?$ & $\mathbf{X}$ & $?$ & & \\
\hline 923 & & & & & & $\mathbf{X}$ & & & & $?$ & & $\mathbf{X}$ & & $\mathbf{X}$ & \\
\hline 907 & & & & & $\mathbf{X}$ & $\mathbf{x}$ & & & $\mathbf{X}$ & & & $\mathrm{X}$ & & $\mathbf{X}$ & $\mathbf{X}$ \\
\hline 906 & & & & & & & & & $\mathbf{X}$ & & & & & & \\
\hline 749 & & & & & & & & & $\mathbf{x}$ & & & & & $\mathbf{X}$ & \\
\hline 747 & & & & & & $\mathbf{X}$ & & & $\mathbf{x}$ & & & & & $x$ & \\
\hline 743 & & & & $\mathbf{X}$ & $\mathbf{x}$ & & & & & & $?$ & $?$ & & & \\
\hline 707 & & & & & X & $\mathbf{X}$ & & & & & & $\mathbf{X}$ & & $\mathbf{X}$ & \\
\hline 703 & & & & & $\mathbf{x}$ & $\mathbf{X}$ & $\mathbf{X}$ & & $\mathbf{x}$ & & & $\mathbf{X}$ & & $\mathbf{X}$ & \\
\hline 683 & & & & & & & & $\mathbf{X}$ & & & & $\mathbf{X}$ & & $\mathbf{X}$ & \\
\hline 681 & & & & & & & $\mathbf{X}$ & $\mathbf{x}$ & & & & & & $\mathbf{X}$ & \\
\hline 678 & & & & & & $X$ & & & $?$ & & & $X$ & & $\mathbf{X}$ & \\
\hline 636 & & & & & & & & & $\mathbf{x}$ & & & $\mathbf{X}$ & & & \\
\hline 620 & & & & & & & & & $\mathbf{X}$ & & & $\mathbf{x}$ & & $\mathbf{x}$ & \\
\hline 616 & & & & & & & & & $\mathbf{X}$ & & & $\mathbf{x}$ & & $\mathbf{x}$ & \\
\hline 569 & & & & & & $\mathbf{X}$ & & & $\mathbf{X}$ & & & & & $\mathbf{X}$ & \\
\hline 568 & & & & & & $X$ & & & $\mathbf{x}$ & & & $\mathbf{X}$ & & $X$ & \\
\hline 564 & & & & & & & $\mathbf{X}$ & & $\mathbf{x}$ & & & $X$ & & & \\
\hline 563 & & & & & $\mathbf{X}$ & $\mathbf{X}$ & & & $\mathbf{X}$ & & & $\mathbf{X}$ & & $\mathbf{X}$ & \\
\hline 558 & & & & & & & & & & & & $\mathbf{x}$ & & $\mathbf{X}$ & \\
\hline 557 & & & & & & & & & & & & $\mathbf{X}$ & & $\mathbf{X}$ & \\
\hline 532 & & & & $\mathbf{X}$ & & $\mathbf{X}$ & & & & & & & & $\mathbf{X}$ & \\
\hline 428 & & & $\mathbf{X}$ & & & & & & & & & & & & \\
\hline 395 & & & $\mathbf{X}$ & & & & & & & & & & & & \\
\hline 330 & & $\mathbf{X}$ & & & & & & & & & & & & & \\
\hline 315 & & $\mathbf{X}$ & & & & & & & & & & & & & \\
\hline 288 & $\mathbf{X}$ & & & & & & & & & & & & & & \\
\hline
\end{tabular}


Table 3

Distribution of Middle Pleistocene Didacna species in the Hajigabul section.

\begin{tabular}{|c|c|c|c|c|c|c|c|c|c|c|c|c|}
\hline $\begin{array}{l}\text { Stratigraphic } \\
\text { level, m }\end{array}$ & $\begin{array}{l}\text { Didacna } \\
\text { parvula }\end{array}$ & $\begin{array}{l}\text { D. cf. } \\
\text { carditoides }\end{array}$ & D. corpulenta $D$ & D. alibajramlinica & D. subpyramidata & D. charamica & D. eulachia & D. trigonula & $\begin{array}{l}\text { D. cf. } \\
\text { gurganica }\end{array}$ & D. subcatillus & D. bergi & D. hospes \\
\hline 1954 & & & & & & & $\mathbf{X}$ & $\mathbf{X}$ & $\mathbf{X}$ & $\mathbf{X}$ & $\mathbf{X}$ & $\mathbf{X}$ \\
\hline 1860 & & & & & $\mathbf{X}$ & $\mathbf{X}$ & $\mathbf{X}$ & $\mathbf{X}$ & & & & \\
\hline 1795 & $\mathbf{X}$ & $\mathbf{X}$ & $\mathbf{X}$ & $\mathbf{X}$ & & & & & & & & \\
\hline
\end{tabular}

Thermomagnetic runs show convex curves that gradually decrease down to $580^{\circ} \mathrm{C}$ (Fig. 11D). We define this carrier as magnetite.

All samples with MT and HT components are combined in two groups: all normal and all reversed (Fig. 11E and F). The mean direction for all normal samples in tectonic coordinates (tc) has parameters of $\mathrm{D}=339.1^{\circ}, \mathrm{I}=49.6^{\circ}, \mathrm{k}=14.2$, a95 $=5.9$ for $\mathrm{N}=45$ (Fig. 11E), while for all reversed samples $\mathrm{D}=204.2^{\circ}, \mathrm{I}=-36.7^{\circ}$, $\mathrm{k}=12.7$, $\mathrm{a} 95=5.7$ for $\mathrm{N}=54$ (Fig. 11F). The mean directions of the ChRM are assumed to be distributed along the dipole axis (Piper and Grant, 1989). Nevertheless, the reversal test is negative. The ChRM directions deviate from the dipole axis towards the West, where the current day overprint (LT_N) is located (Fig. 11G). Thermal demagnetization revealed two different types of demagnetization with either two distinctive magnetic components (Sample DSD2, Fig. $11 \mathrm{H}$ ) or with one component smoothly passing into a second component (samples DS5 and DS 162, Fig. 11I). The latter probably results from an overlap between two coercivity fractions of two magnetic components (Tauxe, 2010). This, in turn declines the ChRM direction towards the West. To verify the second component as original, we measured some doublet samples in alternating field (Fig. 11J).

A separate group of 20 samples contains only one magnetic component. These samples are demagnetized in a wide range of temperatures, between $300^{\circ} \mathrm{C}$ and $580^{\circ} \mathrm{C}$ (Fig. $11 \mathrm{~K}$ ). The mean direction for this group has $\mathrm{D}=8.7^{\circ}, \mathrm{I}=52.1^{\circ}$ in situ (Fig. $11 \mathrm{~L}$ ). It is very close to the present-day local magnetic parameters and we conclude that these samples show "full overprints". For this group of samples, the thermoremanent curves have concave shapes and gradually decrease down to $530-550^{\circ} \mathrm{C}$. After cooling, magnetization of the samples turned back almost to the same level as before the measurement (Fig. $11 \mathrm{M}$ ). Such behaviour suggests that "full overprint" samples have a paramagnetic carrier with a low coercivity.

The polarity pattern of the Hajigabul section comprises four normal and three reversed polarity zones (Fig. 12). Palaeomagnetic investigations started in the sedimentary Unit $\mathrm{H} 1$ at $170.8 \mathrm{~m}$, below the last sandstone of that unit. Here we registered a normal polarity zone (N1) that switches to reversed (R1) at $179.5 \mathrm{~m}$. This reversed zone (R1) continues up to $509.7 \mathrm{~m}$, where a reversal to normal polarity (N2) occurs. A short normal zone (N2) is revealed between 509.7 and $568.2 \mathrm{~m}$. It is followed by a reversed zone (R2) in the interval $568.2-802.5 \mathrm{~m}$, which is again succeeded by a normal zone between 802.5 and $1080 \mathrm{~m}$ (N3). After that, the last reversed zone (R3) extends from $1080 \mathrm{~m}$ to $1641.5 \mathrm{~m}$ and covers the second half of the sedimentary Unit $\mathrm{H} 3$. The last normal zone (N4) starts at $1641.5 \mathrm{~m}$ and continues until the end of section, up to $2050 \mathrm{~m}$. It covers the boundary between the third and fourth sedimentary units. In this zone, we found an interval between $1738 \mathrm{~m}$ and $1775 \mathrm{~m}$ with a set of uncertain magnetic directions. They usually have two magnetic components, but the ChRM directions have incompatible values of declination and inclination. However, most of the measurements made in alternating field suggest a normal polarity (Fig. 12).

\section{Discussion}

\subsection{Correlation to the Global Polarity Time Scale (GPTS)}

\subsubsection{Goychay section}

The polarity pattern of the Goychay section consists of a dominantly reversed polarity interval with three small normal zones (N1-3) of which the middle one (N2) is clearly the longest, separated by four reversed zones (R1, R2, R3 and N4) (Fig. 7). Given the available biostratigraphic age constraints for Units G1 and G2 (Akchagylian/Apsheronian), the reversed polarities are likely to correspond to the Matuyama chron $(2.59-0.78 \mathrm{Ma})$. The most straightforward correlation of the Goychay magnetostratigraphy is then to the middle part of the Matuyama chron where: R1 is correlated to C2r.2r, N1 to C2r.1n (Reunion), R2 to C2r.1r, N2 to C2n (Olduvai), R3 to C1r.3r, N3 to C1r.2n (Cobb Mountain) and R4 to C1r.2r (Fig. 13).

This magnetostratigraphic correlation allows us to assess the average sediment accumulation rates in the section. It shows a gradual upward increase from $1.3 \mathrm{~m} / \mathrm{kyr}$ to $1.68 \mathrm{~m} / \mathrm{kyr}$, in good agreement with the observed coarsening-upward trend in the section (Fig. 13). Extrapolating the sedimentation rate of $1.3 \mathrm{~m} / \mathrm{kyr}$ to the lowermost part, we calculate that the base of the Goychay section has an age of $2.55 \mathrm{Ma}$. It confirms that the upper part of the Gauss chron (2.58 Ma) is not reached here. The major paleoenvironmental change from mesohaline to oligohaline conditions at $110 \mathrm{~m}$ (Fig. 3) is then dated at 2.5 Ma. The major change in depositional environments (From Unit G1 to Unit G2) and the remarkable FCO of Tyrrenocythere azerbaijanica occur slightly above the Reunion subchron and have an age of $\sim 2.1 \mathrm{Ma}$. Extrapolation of the sediment accumulation rate of $1.68 \mathrm{~m} / \mathrm{kyr}$ for the upper part of the section gives an age of $1.13 \mathrm{Ma}$ for the top of the section, confirming that the small normal zone N3 best correlates to the Cobb Mountain subchron (1.215 Ma - 1.178 Ma).

\subsubsection{Hajigabul section}

The polarity pattern of the Hajigabul section shows four normal polarity intervals (N1, N2, N3 and N4) and three reversed polarity intervals (R1, R2 and R3) (Fig. 13). This pattern does not allow for a straightforward correlation to the GPTS and suggests that several subchrons of the GPTS are missing in this record. Our biostratigraphic data constrain the reversed polarity intervals to the Akchagylian-Apsheronian, i.e., to the Gauss and/or Matuyama chrons (maximum ages between 3.6 and $0.78 \mathrm{Ma}$ ). We consider a correlation of N1-3 to the polarity pattern of the Gauss chron highly unlikely, because the two lower reversed intervals are significantly longer than the normal interval N2. Hence, we correlate the lowermost reversed interval to the lower part of the Matuyama chron, conforming to the correlation of the Goychay section. In addition, several other studies have recently determined the Productive Series-Akchagylian transition to occur in the uppermost part of the Gauss chron at an age of 2.7 Ma (Richards et al., 2018; Hoyle et al., 2019; van Baak et al., 2019). Following these results, N1 correlates to chron C2An.1n (upper Gauss), R1 to C2r.2r, N2 to C2r.1n (Reunion), R2 to C2r.1r, N3 to C2n (Olduvai) and R3 to C1r.3r 
(Fig. 13). This magnetostratigraphic correlation dates the Akchagylian-Apsheronian transition in the Hajigabul section within the Reunion subchron at an age of $\sim 2.13 \mathrm{Ma}$.

The long normal zone N4 comprising the Bakunian and Khazarian most likely correlates to C1n (Brunhes) (Krijgsman et al., 2019 and references therein). This implies that the small normal subchrons C1r.2n (Cobb Mountain) and C1r.1n (Jaramillo) are missing in the Hajigabul section. We did not observe clear evidence for a hiatus in the section, but think that the most plausible conclusion is that the upper part of the Apsheronian has been removed by erosion prior to the Bakunian transgression (Fig. 13). An alternative option, correlating from the Brunhes chron downwards, is the magnetostratigraphically feasible correlation of N3-N2 to Jaramillo-Cobb Mountain. However, this would infer an erroneously young age for the uppermost Akchagylian, and can thus be rejected. The presence of lower Khazarian deposits in the upper part of the Hajigabul section indicates an age of $\sim 0.374 \mathrm{Ma}$ (Saltykov, 2011; Krijgsman et al., 2019).

According to our preferred magnetostratigraphic correlation, the sediment accumulation rates are relatively low in the Akchagylian part of the Hajigabul section (Unit H2: $0.76 \mathrm{~m} / \mathrm{kyr}$ ). The sediment accumulation curve increases upwards (1.28-1.66 m/kyr) at the Reunion subchron at $\sim 2.1 \mathrm{Ma}$. This abrupt increase closely coincides with the main paleoenvironmental change from the dark Akchagylian claystones of Unit $\mathrm{H} 2$ to the Apsheronian sandstones of Unit H3 (Fig. 13). Sediment accumulation rates for Unit 3 are not complete due to the hiatus in the uppermost part. This complicates precise dating of the Lower Bakunian transgression (Apsheronian Bakunian boundary) at $1616 \mathrm{~m}$. Rough calculation of sedimentation rates for the R3 zone results in $0.55 \mathrm{~m} / \mathrm{kyr}$ and the age of the Bakunian transgression at $0.85 \mathrm{Ma}$. Sedimentation rates calculated for Unit 4, using two theoretical time points - base of Khazarian Stage at 0.374 Ma (Saltykov, 2011; Krijgsman et al., 2019) and the Matuyama - Brunhes reversal at $0.781 \mathrm{Ma}$, provide a $0.42 \mathrm{~m} / \mathrm{kyr}$ rate and 0.83 age of the Bakunian transgression. Thereby, we estimate the age of the lower Bakunian transgression between 0.85 and $0.83 \mathrm{Ma}$.

\subsection{Palaeoenvironmental evolution}

Here we combine our data on depositional environments, mollusc fauna, microfauna and magnetostratigraphy in chronological order with the aim to provide a reconstruction of palaeoenvironments in the Kura Basin in the South Caspian region. The ages of the key events are acquired through extrapolation of average sedimentation rates that are derived from our magnetostratigraphic correlations (Fig. 13).

\subsubsection{The Productive Series - Akchagylian transition (Hajigabul section, 2.7-2.6 Ma)}

The Productive Series - Akchagylian transition is marked by a major transgressive event. Fluvial sandstones with freshwater faunas of the Productive Series (H1) are overlain by distal openwater claystones with oligohaline faunas of the Akchagylian (H2). This transition is present only in the Hajigabul section where it is roughly dated at the top of the Gauss chron at an estimated age of $\sim 2.6 \mathrm{Ma}$. In the Goychay section, the transition is not exposed because a major thrust fault cuts through the sedimentary succession above this level (Fig. 1c), (Forte et al., 2013).

Depositional environments and corresponding freshwater microfauna described in the Productive Series (Unit H1) of the Hajigabul section are similar to other sections in the Kura Basin (Lokbatan, Jeirankechmez, Babazanan) (Vincent et al., 2010; van Baak et al., 2013). Transition, from continental to deep-water offshore environments between $175 \mathrm{~m}-205 \mathrm{~m}$ is interpreted as the Akchagylian transgression. This transitional Productive Series Akchagylian interval in our section, unfortunately, lacks micropalaeontological data. The biostratigraphic samples from $210 \mathrm{~m}$ onwards reveal rich oligohaline ostracod assemblages, representative for the Akchagylian stage. In the other sections across the Kura Basin, the Akchagylian transgression is characterized by marine benthic foraminifera, including species of Cassidulina and Cibicides, and marine dinocysts (Algidasphaeridium cf. capillatum) indicating a potential influx of Arctic waters (Richards et al., 2018; Hoyle et al., 2019). The transitional interval in Hajigabul is, however, marked by the presence of several volcanic ash layers. We assume that these are similar to those present within the transitional interval in the Jeirankechmez and Lokbatan sections, that were recently radio-isotopically $\left({ }^{40} \mathrm{Ar} /{ }^{39} \mathrm{Ar}\right.$ ) dated at $2.7-2.6 \mathrm{Ma}$ (van Baak, 2015; Hoyle et al., 2019; van Baak et al., 2019). Our results are thus in good agreement with the other sections in the Kura Basin.

\subsubsection{The Akchagylian (Hajigabul and Goychay, 2.6-2.1 Ma)}

The major part of the Akchagylian deposits in both the Goychay and Hajigabul sections consists of grey mudstones, representing offshore depositional environments with mostly anomalohaline faunas. The Hajigabul section has an impoverished Akchagylian fauna. Indicative Akchagylian species such as Cerastoderma dombra and Avimactra subcaspia are lacking: the habitat of these species likely was very shallow while depositional depths in the Hajigabul were deeper (Paramonova, 1994; Danukalova, 1996). In the Hajigabul section, deep water facies contain rare, poorly-preserved cardiids, the Akchagylian-indicative gastropod Pirenella caspia and bivalve Avicardium nikitini (Fig. 9), and anomalohaline ostracod associations (Fig. 8). Despite a presence of rare molluscs, no foraminifers have been detected in the lowermost Akchagylian part of the section, which might be linked with bad preservation potential of foraminifers in this particular interval or with low micropalaeontological sampling resolution.

Indicative Akchagylian bivalve species have not been found in the Goychay section. The lowermost part contains brackish water ostracods and abundant foraminifera indicating mesohaline conditions. Above $99.4 \mathrm{~m}$, foraminifera disappear and brackish ostracods decline both in abundance and species numbers, indicating a decrease of salinity. The transition from mesohaline to oligohaline conditions in Goychay is dated at $2.5 \mathrm{Ma}$. A similar switch to lower salinity faunas has been described in the Jeirankechmez section, where it was interpreted to correlate to the termination of marine Arctic waters entering the Caspian Basin (van Baak et al., 2019). Starting from 2.4 Ma, the Goychay section displays first prodeltaic facies that are associated with freshwater/oligohaline mollusc groups with Theodoxus, Corbicula and hydrobiids (Fig. 3, Table 1). Presence of lower salinity fauna in prodeltaic facies suggests freshening of the basin margins due to local river fresh water input. Such early deltaic progradation in this area likely happened due to progradation of the Kura thrust-fold belt that turned the Goychay area into a semi-isolated piggy-back basin (Forte et al., 2013). The absence of Akchagylian indicator bivalve species in the Goychay section can be explained by the presence of an unsuitable habitat: fast transition from deep-water environments $(0-120 \mathrm{~m})$ to freshened conditions of prodelta with low oligohaline/freshwater fauna $(120-675 \mathrm{~m})$. Another interesting aspect of the Goychay faunal record is the presence of Caspia species gastropods (Caspia matura and $C$. apsheronica). These gastropod species have so far only been reported from Apsheronian deposits, yet they may have been present already in marginal Akchagylian environments.

Similar complications in the upper Akchagylian are known from the sections in West Turkmenia, where freshening of marginal parts of the basin caused the depletion of Akchagylian indicator 


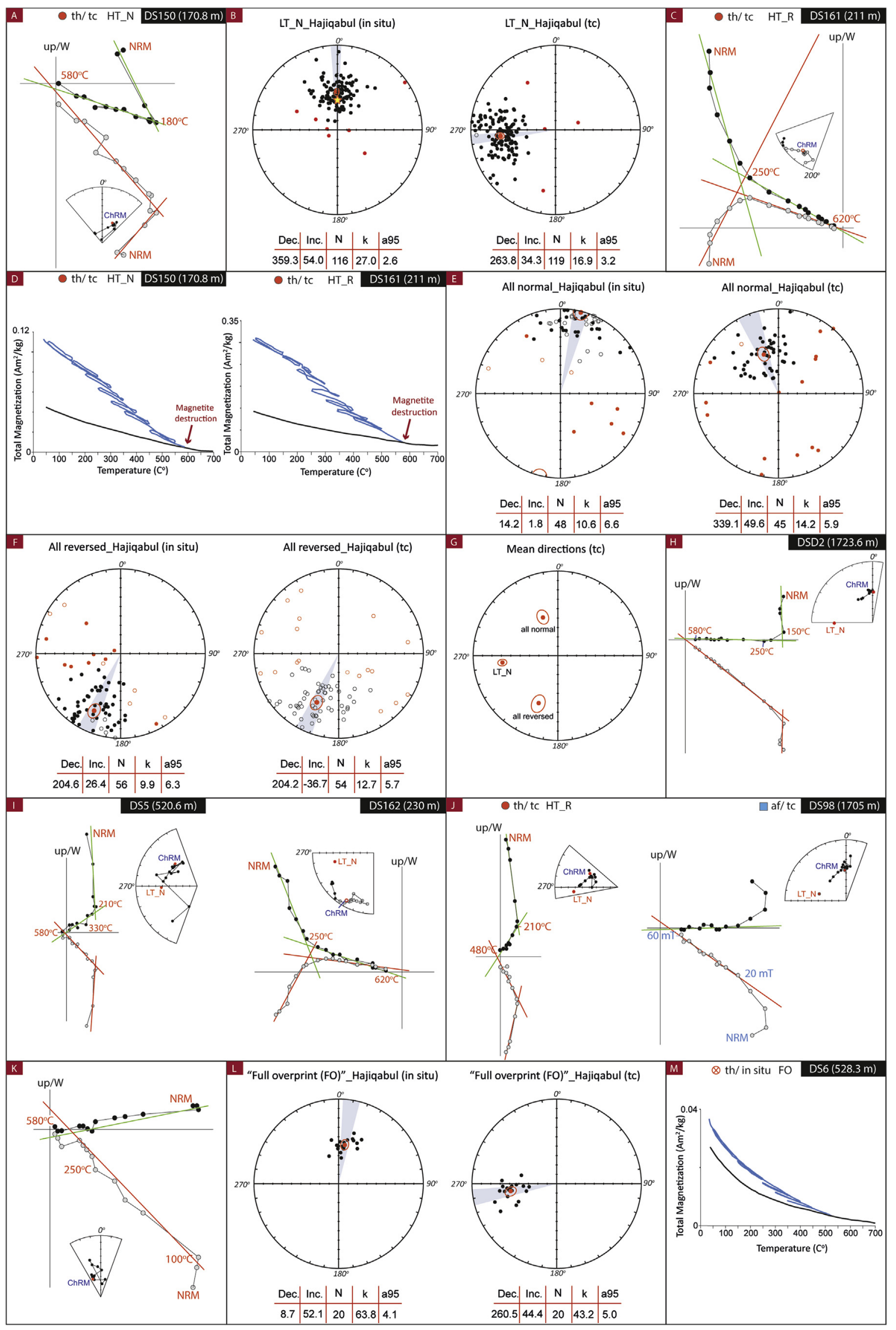

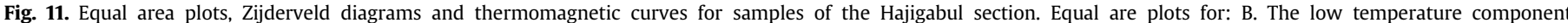

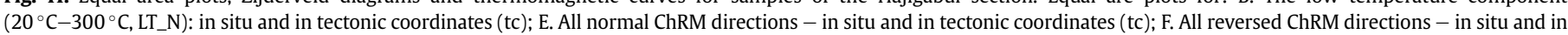

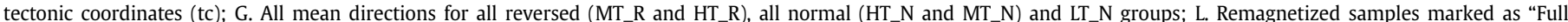

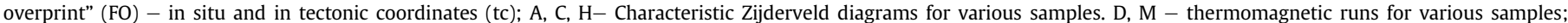

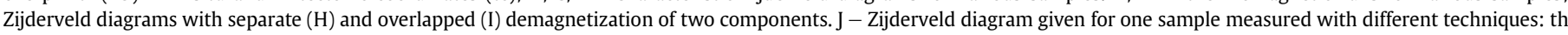
- thermally demagnetized, af - demagnetized in alternating field. 


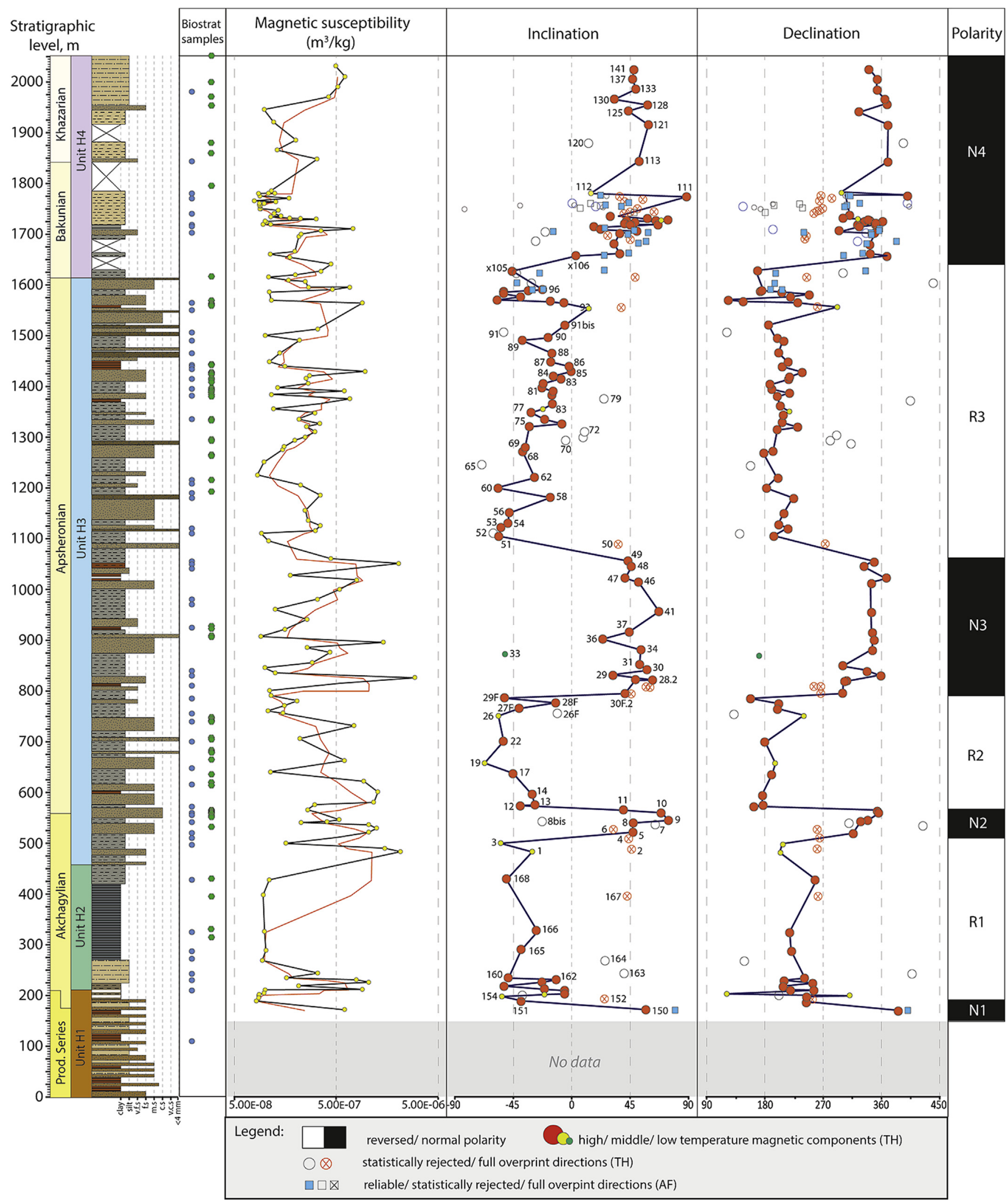

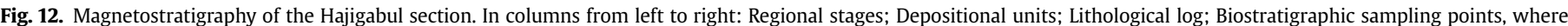

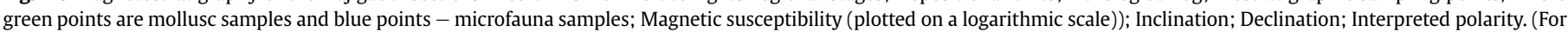
interpretation of the references to colour in this figure legend, the reader is referred to the Web version of this article.) 


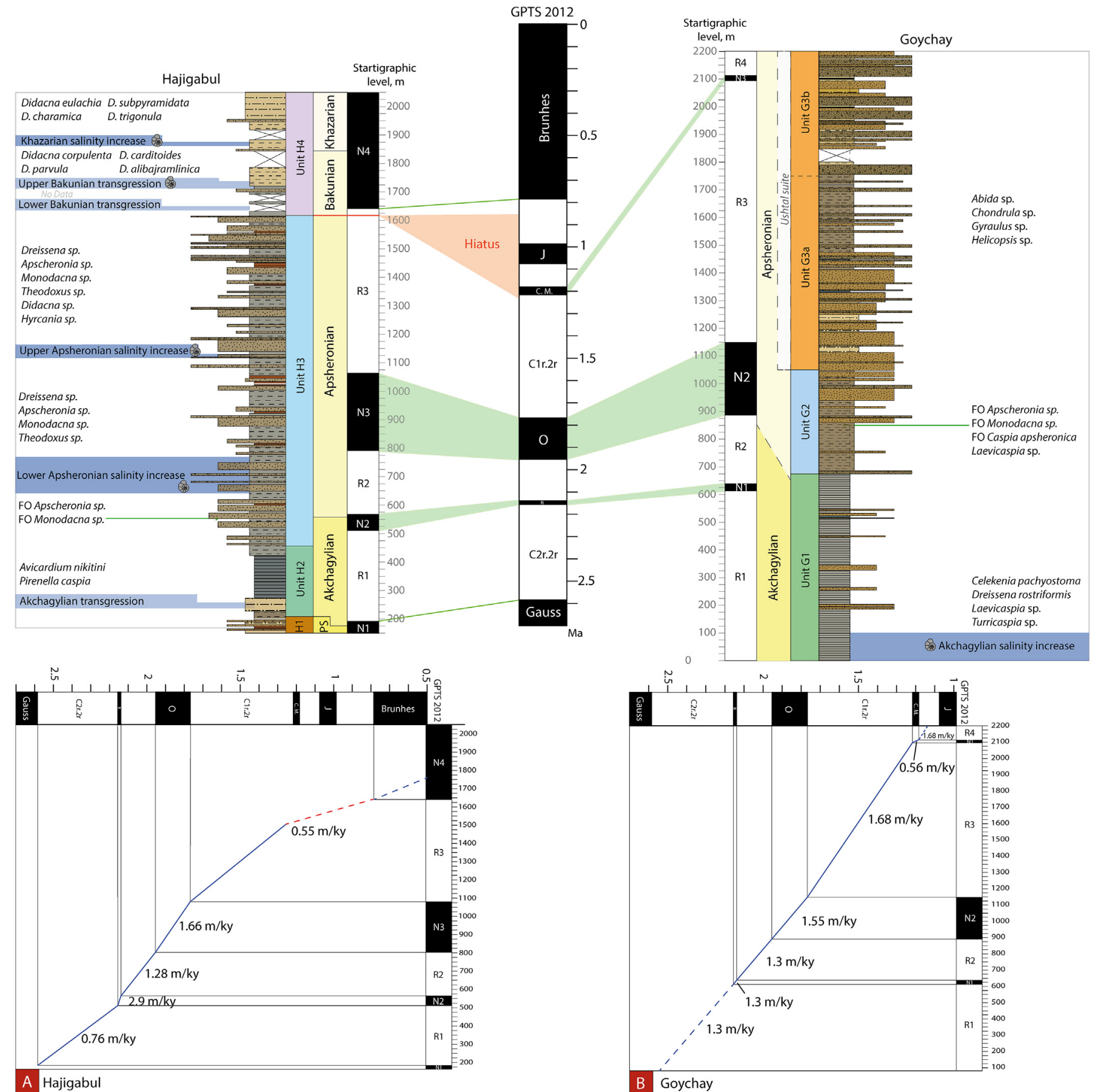

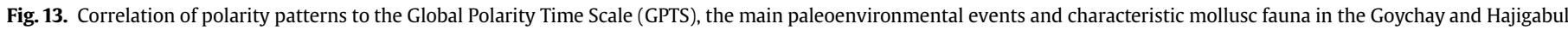
sections. Sedimentation rate curves: Hajigabul section (A), the Goychay section (B).

molluscs (Markova, 1962). There, non-indicative hydrobiid and dreisseniid species prevail over a low number of Akchagylian molluscs species and thus leave open the question of a clear Akchagylian - Apsheronian boundary in that region (Markova, 1962).

In the west Kura Basin (Kvabebi) and West Turkmenia (Pyrnaur), the inidicative Akchagylian molluscs of genera Avicardium, Avimactra, Pirenella etc. are the most abundant in shallow water facies (limestones, sandstones) (Danukalova, 1996; Agustí et al., 2009). In Hajigabul, the scare molluscs were found in the clayey Unit H2 that was interpreted to be deposited in distal open-water environments.
Thereby, we assume that the Akchagylian depositional environments in Hajigabul could be unfavourable (too deep) for the indicative Akchagylian molluscs, that explains their scarce distribution and poor preservation.

\subsubsection{The Akchagylian - Apsheronian transition (Hajigabul and Goychay, $2.1 \pm 0.1 \mathrm{Ma}$ )}

The Akchagylian - Apsheronian transitional interval is characterized by a lithological regressive trend and occurrence of new mollusc groups. Both the Hajigabul and Goychay sections show a sudden increase in coarser clastic material (sandstones or 
conglomerates; Unit H3 and G2). The first sandstones in Hajigabul occur at $457 \mathrm{~m}$ marking the onset of the regressive trend (boundary $\mathrm{H} 2-\mathrm{H} 3$, Fig. 8). Above in the section, sandstones become coarser and pass into short interval with terrestrial facies represented by medium-grained sandstones and paleosoils at $616 \mathrm{~m}$ (Fig. 8) (Jorissen et al., 2019). In Goychay, the beginning of the regressive trend is not clear due to turbidite layers within unit G1 (Fig. 3). However, the first shallow water facies expressed as a thick conglomerate bed occur at $675 \mathrm{~m}$ (boundary G1-G2, Fig. 3). The level $675 \mathrm{~m}$ in Goychay and $616 \mathrm{~m}$ in Hajigabul are chronostratigraphically synchronous and dated at 2.1 Ma. The appearance of these facies in Goychay was previously linked to the initiation of the Akharbakhar thrust system (Forte et al., 2013). However, as these shallow facies occur simultaneously in paleogeographically remote sections, we assume that they might be related to a larger, basinscale paleoenvironmental change. In the Caspian Basin, the upper Akchagylian was described as a regressive interval that occurred around the Reunion subchron $(2.12-2.14 \mathrm{Ma})$ (Zubakov, 1974; Yakhimovich and Suleymanova, 1981; Zubakov and Borzenkova, 1990). Thereby, we assume that the shallowing/prograding trend in both sections at $2.1 \mathrm{Ma}$ is linked to regression of the Caspian Basin that occurred in the end of Akchagylian. The AkchagylianApsheronian transitional interval in Hajigabul (557-616 m) comprises a change in fauna, showing the first occurrences of indicative Apsheronian mollusc species Monodacna sp. (557 m) and Apscheronia propinqua $(563 \mathrm{~m})$, the ostracod species Tyrrhenocythere azerbaijanica $(616 \mathrm{~m})$ and presence of benthic foraminifera (616 $\mathrm{m})$. This transitional interval is magnetostratigraphically dated between 2.13 and $2.10 \mathrm{Ma}$ (Figs. 8 and 13). We therefore propose to place the Akchagylian - Apsheronian boundary at $557 \mathrm{~m}$ (FO of Monodacna sp.), which is dated at $2.13 \mathrm{Ma}$ - in the middle of the Reunion subchron (Fig. 13). In Goychay, the bio-events are more spread throughout the section that makes determination of the Akchagylian - Apsheronian boundary there less certain. The FCO of Tyrrhenocythere azerbaijanica in Goychay is also observed at $\sim 2.1 \mathrm{Ma}(651 \mathrm{~m})$, while the first indicative Apsheronian mollusc Apscheronia propinqua occurs at $849 \mathrm{~m}$ that is dated at $2.0 \mathrm{Ma}$ (Table 1., Fig. 13). Therefore, we cannot clearly state the Akchagylian - Apsheronian boundary in the Goychay section and thus, we place it between 2.1 Ma (FCO of Terrhynocythere) and 2.0 Ma (FO of Apscheronia propinqua) (Fig. 13).

The newly occurred Apsheronian molluscs dominated by Monodacna and Apscheronia bivalve occur in shallow water facies similar habitat as for the Akchagylian molluscs around the Caspian Basin (Paramonova, 1994; Danukalova, 1996; Agustí et al., 2009). The absence of the latter ones suggests their extinction prior to occurrence of the first indicative Apsheronian bivalves and thus marks the major mollusc fauna turnover.

Despite a lack of major microfauna changes at the Akchagylian Apsheronian boundary across the Kura Basin (Krijgsman et al., 2019), we noticed one remarkable synchronous bio-event in our sections - the FCO of Tyrrhenocythere genus (Figs. 3 and 8). This bio event can potentially be used for clarification of the Akchagylian Apsheronian boundary in other regional sections like the Jeirankechmez and Lokbatan sections, where polarity patterns and mollusc fauna are not as clear (Richards et al., 2018; van Baak et al., 2019). In Jeirankechmez, the boundary was placed at $2.4 \mathrm{Ma}$ $(835.98 \mathrm{~m})$ by abundant occurrence of several Amnicythere species (Richards et al., 2018). In Lokbatan, the Akchagylian - Apsheronian boundary was established at $2.0 \mathrm{Ma}$ by the FO of Tyrrhenocythere azerbaijanica (van Baak et al., 2013). In both sections, polarity patterns at the Akchagylian - Apsheronian transition are not representative but the FCO of Tyrrhenocythere genus can be well traced.

The Akchagylian-Apsheronian boundary was commonly placed at the first normal chron after the Gauss-Matuyama boundary, previously interpreted as Olduvai (Trubikhin, 1977; Kochegura and Zubakov, 1978; Semenenko and Pevzner, 1979; Sidnev, 1985). The first occurrence of species such as Monodacna sp. and Apscheronia propinqua in the middle part of the Reunion subchron indicates the onset of the Apsheronian there. This contradiction is probably linked to the absence of the Reunion subchron in old GPTSs, hampering correct magnetostratigraphic correlations in the past. Here, we confirm that the Akchagylian-Apsheronian boundary in the Kura Basin corresponds to the first normal subchron of the Matuyama, but that this correlates to the Reunion subchron instead of the Olduvai subchron and has an age $\sim 2.1 \mathrm{Ma}$.

\subsubsection{The Apsheronian (Hajigabul and Goychay, 2.1-0.85 Ma)}

During the Apsheronian, depositional environments in the Goychay section were strongly controlled by the prograding Kura thrust-fold belt (Forte et al., 2015). It resulted in a transition to continental environments of the Unit G3 and disappearance of basinal mollusc fauna. The last Apsheronian mollusc was found at $1017.8 \mathrm{~m}$ (middle of the Olduvai chron; $1.9 \mathrm{Ma}$ ). At $1050 \mathrm{~m}$ the lacustrine deposits are fully replaced by continental floodplain deposits that contain terrestrial mollusc species, such as Abida sp., Chondrula sp., Gyraulus sp. and Helicopsis sp. (1620 m) (Forte et al., 2013). The $1050 \mathrm{~m}$ point is considered the base of the local continental Ushtal Suite, dated in Goychay at $\sim 1.85$ Ma.

In Hajigabul, the Akchagylian - Apsheronian transition was followed by a $\sim 100 \mathrm{kyr}$ long interval $(616-755 \mathrm{~m})$ with elevated, mesohaline salinity conditions between the Reunion and Olduvai subchrons (2.1 Ma - 2.0 Ma) (Fig. 13). This interval contains a rich Apsheronian mollusc assemblage with Apscheronia propinqua, Monodacna sp. and Dreissena rostriformis (Table 2), ostracod species Tyrrhenocythere, Euxinocythere praebosqueti, Loxoconcha babazananica and Limnocythere alveolata and abundant foraminifera Ammonia, Cibicides and Cassidulina (Fig. 8).

After 2.0 Ma, the Apsheronian faunas in the Hajigabul section show fluctuations between oligohaline and freshwater fauna assemblages (Fig. 8). This mirrors the sedimentary facies that display numerous repetitive shallowing trends, from distal offshore settings to coastal and continental environments (Jorissen et al., 2019). Within both offshore and littoral environments, oligohaline assemblages are common. Among them are the ostracod species of Loxoconcha, Amnicythere, Limnocythere (Fig. 8). Shallow lacustrine, coastal, continental and lagoon settings mainly contain freshwater assemblages, including Ilyocypris bradyi, Darwinula stevensoni, Candona sp. It proves that the marginal areas of the anomalohaline lake have been periodically influenced by freshwater input and points towards a close link between depositional environments and the spatial distribution of the fauna.

In the Hajigabul section, a short flooding interval with abundant foraminifera is present at $1110 \mathrm{~m}$ ( 1.7 Ma; Fig. 13), slightly younger than the top of the Olduvai. The close correspondence with the first occurrence of Didacna sp. at 1190 m suggests a (re-)connection to the Black Sea, possibly marking the lower-upper Apsheronian boundary (Nevesskaya and Trubikhin, 1984).

Another remarkable taxonomic microfauna enrichment was discovered between 1465 and $1490 \mathrm{~m}$, where seven new ostracod species occurred: Loxoconcha rugosa, L. lepida, L. endocarpus ?, Candona schweyeri, Tyrrhenocythere donetziensis, Bakunella dorsoarcuata, Cypria sp. (Figs. 8 and 13). Among these species, the Bakunella dorsoarcuata is known from the Kuyalnikian deposits time analogue of the Productive Series - Akchagylian in the Black Sea (Krijgsman et al., 2019). The other species are widely distributed in Bakunian and Khazarian deposits of the Caspian Sea, when periodical interbasinal Caspian - Black Sea connections were common via the Manych Strait (Svitoch et al., 2010). The massive occurrence of these forms in Apsheronian may suggest that already 
at that time the Caspian Sea experienced periods of reconnection and faunal exchange with the Black Sea.

\subsubsection{The Apsheronian-Bakunian transition (Hajigabul; $\sim 0.85-0.83 \mathrm{Ma}$ )}

The Apsheronian - Bakunian boundary is marked by a transgression expressed in the section as an abrupt replacement of sandstones of Unit H3 by grey clays of Unit H4 (Fig. 8 and $1614 \mathrm{~m}$ ). Due to low micropalaeontological sampling resolution in this part of the section, we have no biostratigraphic characteristic for the lower Bakunian transgression and thus, the Apsheronian - Bakunian boundary is defined here lithologically.

The roughly estimated age of the Apsheronian - Bakunian boundary (explained in paragraph 5.1 .2 ) between 0.83 and $0.85 \mathrm{Ma}$ is in a good agreement with magnetostratigraphic study of the Xocashen section (Azerbaijan) that provided an age of $0.85 \mathrm{Ma}$ for the Bakunian transgression (van Baak et al., 2013). It is, however, in contrast to other studies that correlated the base of the Bakunian to the Matuyama - Brunhes polarity reversal at $0.78 \mathrm{Ma}$ (Trubikhin, 1977; Kochegura and Zubakov, 1978; Semenenko and Pevzner, 1979; Yakhimovich et al., 2000; Zastrozhnov et al., 2013).

\subsubsection{The Bakunian and Khazarian (Hajigabul, 0.85-0.3 Ma)}

After the Lower Bakunian transgression, another, smaller scale transgressive event was observed at $1714 \mathrm{~m}$. Abundant presence of foraminifera like Ammonia sp., Cassidulina sp. and Porosononion sp. indicate an elevated, mesohaline salinity level (Fig. 8). The molluscs Didacna corpulenta, D. parvula, $D$. cf. carditoides and D. alibajramlinica observed at $1795 \mathrm{~m}$ (Figs. 10 and 13) are indicative for the upper Bakunian (Nevesskaja, 2007; Yanina, 2012, 2013). Thereby, the Bakunian Stage in the Hajigabul section displays two lithologically defined transgression events with characteristic Upper Bakunian mollusc fauna occurring in the section above the second transgression. Division of the Bakunian stage into two substages is based on different associations of Didacna molluscs, highlighting two transgression events (Shantser, 1982; Yanina, 2013).

The upper Bakunian interval $1719 \mathrm{~m}-1842 \mathrm{~m}$ is characterized by a regressive trend showing a lithological change from offshore clays to nearshore silts. At $1842 \mathrm{~m}$, we discovered an influx of foraminifera such as Ammonia sp, Cibicides sp., Cassidulina sp. and Porosononion sp. (Fig. 8). Above, at 1860 m, we observed lower Khazarian fauna with indicative Didacna eulachia, D. subpyramidata, $D$. charamica, D. trigonula. The species $D$. eulachia has been used in the past as an indicator for the so-called Urundzhikian substage, but has later been recorded in Khazarian deposits as well (Yanina, 2013). The following assemblage, discovered at $1954 \mathrm{~m}$ with Didacna bergi, D. hospes, D. cf. gurganica, D. trigonula, D. eulachia and D. subcatillus and Corbicula cf. fluminalis has an early Khazarian Age (Nevesskaja, 2007).

Thereby, we assume, that increase of salinity at $1842 \mathrm{~m}$, followed by occurrence of Khazarian mollusc assemblages, represents the onset of the Khazarian Stage. The upper Bakunian and Khazarian deposits are situated within the Brunhes chron and could not be dated with the magnetostratigraphic approach. The recent data indicate the beginning of the Khazarian Stage close to MIS 10 and dated around 0.37-0.38 Ma Ma (Saltykov, 2011; Krijgsman et al., 2019 and references therein).

\section{Conclusion}

Integration of magneto- and biostratigraphy in two wellexposed sections in the Kura Basin allowed creating a solid stratigraphic framework for the Early - Middle Pleistocene history of the Caspian region. The age estimates of the regional stages have been revised: Productive Series - Akchagylian boundary situates around the Gauss-Matuyama reversal and is dated at $2.6 \pm 0.1 \mathrm{Ma}$; Akchagylian - Apsheronian Boundary is correlated to the middle of the Reunion subchron at $\sim 2.13 \mathrm{Ma}$; Apsheronian - Bakunian boundary occurs slightly below the Brunhes - Matuyama reversal at 0.85-0.83 Ma.

We discovered several major intervals with elevated (mesohaline) salinity: 2.6-2.5 Ma (base of the Akchagylian), 2.1-2.0 Ma (base of the Apsheronian), $1.7 \mathrm{Ma}$ (middle part of the Apsheronian), and two intervals within the Brunhes chron: upper Bakunian and lower Khazarian. Each of these intervals is closely related to the occurrence of new mollusc and microfauna taxa in the stratigraphic record that may be linked to the establishment of interbasinal connections of the Caspian Basin with the Arctic Ocean (for the base of Akchagylian) and with the Black Sea (for Apsheronian, Bakunian and Khazarian salinity increases).

High resolution dating of the biotic record in two paleogeographically remote sections showed that first occurrence and further dispersion of the age-indicative molluscs is highly dependent on the depositional environments and in different parts of the basin may demonstrate diachronic occurrence. This implies a high importance of the integrative approach in evaluation of the regional boundaries.

\section{Acknowledgments}

We thank Tom Hoyle, Vusala Aghayeva, Rashad Amrahov, Sevinj Shiraliyeva, Gülçin Aygün and the research staff of the Geological and Geographic Institutes of the National Academy of Sciences of Azerbaijan for assistance in the field. We thank Guzel Danukalova for help with the Akchagylian cardiid identifications. The suggestions of three reviewers including Imre Magyar, have been very helpful to improve our manuscript. The research is part of the PRIDE project (Pontocaspian RIse and DEmise), which is funded by the European Union's Horizon 2020 research and innovation program, under the Marie Sklodowska-Curie Action (grant agreement № 642973). This paper is dedicated to the establishment of peace in the Caucasian region.

\section{Appendix A. Supplementary data}

Supplementary data to this article can be found online at https://doi.org/10.1016/j.quascirev.2019.105895.

\section{References}

Abdullayev, N.A., Kadirov, F., Guliyev, I.S., 2017. Subsidence history and basin-fill evolution in the South Caspian Basin from geophysical mapping, flexural backstripping, forward lithospheric modelling and gravity modelling. Geol. Soc Lond. Spec. Publ. 427 (1), 175-196. https://doi.org/10.1144/SP427.5.

Abdullayev, N.R., Weber, J., van Baak, C.G.C., Aliyeva, E., Leslie, C., Riley, G.W., O'Sullivan, P., Kislitsiyn, R., 2018. Detrital zircon and apatite constraints on depositional ages, sedimentation rates and provenance: Pliocene Productive Series, South Caspian Basin, Azerbaijan. Basin Res. 30 (5), 835-862. https:/ doi.org/10.1111/bre.12283.

Agustí, J., Vekua, A., Oms, O., Lordkipanidze, D., Bukhsianidze, M., Kiladze, G., Rook, L., 2009. The Pliocene-Pleistocene succession of Kvabebi (Georgia) and the background to the early human occupation of Southern Caucasus. Quat. Sci. Rev. 28 (27-28), 3275-3280. https://doi.org/10.1016/j.quascirev.2009.09.001.

Aliyeva, E.G.M., 2005. Reservoirs of the lower Pliocene productive series at the western flank of the South Caspian basin. Lithol. Miner. Resour. 40 (3), 267-278. https://doi.org/10.1007/s10987-005-0027-7.

Ali-Zade, A.A., 1961. Ackhagylian of Turkmenistan. GOSGEOLTEKHIZDAT, Moscow. Alizadeh, A.A., Guliyev, I.S., Kadirov, F.A., Eppelbaum, L.V., 2016. Geosciences of Azerbaijan. Springer International Publishing, Cham.

Allen, M.B., Jones, S., Ismail-Zadeh, A., Simmons, M., Anderson, L., 2002. Onset of subduction as the cause of rapid Pliocene-Quaternary subsidence in the South Caspian basin. Geology 30 (9), 775. https://doi.org/10.1130/0091-7613(2002) 030<0775:OOSATC>2.0.CO;2.

Allen, M.B., Vincent, S.J., Alsop, G.I., Ismail-Zadeh, A., Flecker, R., 2003. Late Cenozoic 
deformation in the South Caspian region: effects of a rigid basement block within a collision zone. Tectonophysics 366 (3-4), 223-239. https://doi.org/ 10.1016/S0040-1951(03)00098-2.

Andrusov, N., 1902. Beiträge zur Kenntniss des Kaspischen Neogen. Die Aktschagylschichten. Proc. Geo. Comm. 15 (4).

Andrusov, N., 1918. Relationships of Euxinian and Caspian Basins in the Neogene Epoch. Bulletin of the Russian Academy of Sciences.

Andrusov, N.I., 1923. Apsheronian stage. Proc. Geol. Comm. 110.

Arslanov, N.V., Lokshin, A.V., Mamedov, A.V., 1988. On age constraints of Khazarian, Khvalynian and Neocaspian deposits of the Caspian Sea. Bull. Comm. Study Quat. Period (57), 28-38.

Asadullayev, E.M., Pevzner, M.A., 1973. Paleomagnetic investigations of marine Anthropohene deposits of the Maliy Kharami ridge. Izv.Acad.Sci. USSR, Ser. Geol. 1.

Azizbekov, S.A. (Ed.), 1972. Geology of the USSR: Azerbaijan SSR, vol. 47. Nedra, Moscow.

Bairamov, A.A., Aliyev, G.I., Hasanov, G.M., Hasanov, H.Y., Hasanov, T.A., IsmailZadeh, A.J., Kangarli, T.N., Korobanov, V.V., Mamedov, A.I., Mamedov, A.V. Mustafayev, H.V., Nagiyev, A.N., Narimanov, A.A., Rustamov, M.I., Zamanov, Y.J. 2008. Geological Map of Azerbaijan Republic. National Academy of Sciences of Azerbaijan Republic, Ministry of Ecology and Natural Resources of Azerbaijan Republic and Ministry of Fuel and Energetics of Azerbaijan Republic, Baku.

Barbot-de-Marni, N.P., Simonovich, S., 1891. Geological exploration of the Binagad oil-bearing region of the Absheron Peninsula. Tiflis.

Bludorova, E.A., Vasiliev, Y.M., Zhidovinov, N.Y., Karmishina, G.I., Nemkova, V.K., Nikiforova, K.V., Popova-Lvova, M.G., Chiguryaeva, A.A., Yakhimovich, V.L., 1983. Apsheronian time of the East-european plain. Bull. Comm. Study Quat. Period (52), 3-17.

Bogachev, V.V., 1940. Apsheronian fauna in the Azov Sea Basin. Nature (Priroda) 12

Borissjak, A.A. (Ed.), 1937. Stratigraphical Dictionary of the USSR. ONTI NKTP USSR Moscow, Leningrad.

Brunet, M.-F., Korotaev, M.V., Ershov, A.V., Nikishin, A.M., 2003. The South Caspian Basin: a review of its evolution from subsidence modelling. Sediment. Geol. 156 (1-4), 119-148. https://doi.org/10.1016/S0037-0738(02)00285-3.

Channell, J.E.T., 2017. Cobb mountain subchron recorded at IODP site U1306 (eirik drift, off SE Greenland). Geophys. J. Int. 209 (3), 1389-1397. https://doi.org/ $10.1093 / \mathrm{gji} / \mathrm{ggx} 098$

Danukalova, G.'A., 1996. Bivalves and stratigraphy of the Akchagylian. Proc. Paleontol. Inst. 265 (Nauka, Moscow).

Dunlop, D.J., Ozdemir, O., 1997. Rock Magnetism. Cambridge University Press, Cambridge.

Fedorov, P.V., 1957. Stratigraphy of the Quaternary Deposits and History of the Caspian Sea Development, vol. 10. AS USSR, Proceedings of the Geological Institute.

Forte, A.M., Cowgill, E., Bernardin, T., Kreylos, O., Hamann, B., 2010. Late Cenozoic deformation of the Kura fold-thrust belt, southern Greater Caucasus. Tectonophysics 122 (3-4), 465-486. https://doi.org/10.1130/B26464.1.

Forte, A.M., Cowgill, E., Murtuzayev, I., Kangarli, T., Stoica, M., 2013. Structural geometries and magnitude of shortening in the eastern Kura fold-thrust belt Azerbaijan: implications for the development of the Greater Caucasus Mountains. Tectonics 32 (3), 688-717. https://doi.org/10.1002/tect.20032.

Forte, A.M., Sumner, D.Y., Cowgill, E., Stoica, M., Murtuzayev, I., Kangarli, T., Elashvili, M., Godoladze, T., Javakhishvili, Z., 2015. Late Miocene to Pliocene stratigraphy of the Kura Basin, a subbasin of the South Caspian basin: implications for the diachroneity of stage boundaries. Basin Res. 27 (3), 247-271. https://doi.org/10.1111/bre.12069.

Green, T., Abdullayev, N., Hossack, J., Riley, G., Roberts, A.M., 2009. Sedimentation and subsidence in the South Caspian basin, Azerbaijan. Geol. Soc. Lond. Spec. Publ. 312 (1), 241-260. https://doi.org/10.1144/SP312.12.

Gurarii, G.Z., 2015. Some data on the characteristics of the geomagnetic field at the Gauss-Matuyama magnetic chron boundary from the Pirnuar section, West Turkmenistan. Izv. Phys. Solid Earth 51 (5), 651-673. https://doi.org/10.1134| S1069351315050055.

Hilgen, F.J., Lourens, L.J., van Dam, J.A., Beu, A.G., Boyes, A.F., Cooper, R.A., Krijgsman, W., Ogg, J.G., Piller, W.E., Wilson, D.S., 2012. The Neogene period. In: The Geologic Time Scale. Elsevier, pp. 923-978.

Hoyle, T.M., Leroy, S.A.G., Lopez-Merino, L., Miggins, D.P., Koppers, A.A.A.P., 2019 Vegetation succession and climate change across the Plio-Pleistocene transition in eastern Azerbaijan (2.77-2.45 Ma) (accepted). Palaeogeogr. Palaeoclimatol. Palaeoecol.

Jackson, J., Priestley, K., Allen, M., Berberian, M., 2002. Active tectonics of the South Caspian basin. Geophys. J. Int. 148 (2), 214-245. https://doi.org/10.1046/j.1365246X.2002.01005.x

Jones, R.W., Simmons, M., 1997. A Review of the Stratigraphy of Eastern Paratethys (Oligocene-Holocene), with Particular Emphasis on the Black Sea. AAPC Memoir.

Jorissen, E., Abels, H., Wesselingh, F., Lazarev, S., Aghayeva, V., Krijgsman, W., 2019 Amplitude, frequency and drivers of Caspian Sea lake-level variations during the Early Pleistocene and their impact on a protected wave-dominated coastline. Sedimentology. https://doi.org/10.1111/sed.12658.

Khain, V.E., Bogdanov, V.I., Popkov, V.I., Chekhovich, P.A., 2004. Major geostructures and basic features of the development of caspian oil and gas megabasins. Ecol. Bull. Res. Cent. Black Sea Econ. Coop. (2), 47-56.

Scale 1:2500000. In: Khain, V.E., Popkov, V.I. (Eds.), 2009. Tectonic of the South
Border of the East European Platform: Explanatory Letter to the Tectonic mp of the Black Sea - Caspian Sea Region. Kuban State University, Krasnodar.

Khramov, A.N., 1960. Paleomagnetism and Stratigraphic Correlation, Canberra.

Khramov, A.N., 1963. Paleomagnetic sections of Pliocene and Post-Pliocene of the Apsheronsk-Trancaucasian region and their correlation. Proc. All Union Pet. Res. Explor. Inst. (VNIGRI) 204, 253-262.

Kochegura, V.V., Zubakov, V.A., 1978. Palaeomagnetic time scale of the PontoCaspian Plio-Pleistocene deposits. Palaeogeogr. Palaeoclimatol. Palaeoecol. 23, 151-160. https://doi.org/10.1016/0031-0182(78)90087-1.

Kolesnikov, V.P., 1950. The Akchagyl and Apsheron mollusks. Paleontol. USSR $10-13$

Koymans, M.R., Langereis, C.G., Pastor-Galan, D., Hinsbergen, D.J.J., 2016. Paleomagnetism.org: an online multi-platform open source environment for paleomagnetic data analysis. Comput. Geosci. 93, 127-137.

Krasnov, I.I. (Ed.), 1984. Stratigraphy of the USSR: Quaternary System 2. Nedra, Moscow.

Krijgsman, W., Stoica, M., Vasiliev, I., Popov, V.V., 2010. Rise and fall of the Paratethys sea during the Messinian salinity crisis. Earth Planet. Sci. Lett. 290 (1-2), 183-191. https://doi.org/10.1016/j.epsl.2009.12.020.

Krijgsman, W., Tesakov, A., Yanina, T., Lazarev, S., Danukalova, G., van Baak, C.G.C., Agustí, J., Alçiçek, M.C., Aliyeva, E., Bista, D., Bruch, A., Büyükmeriç, Y., Bukhsianidze, M., Flecker, R., Frolov, P., Hoyle, T.M., Jorissen, E.L., Kirscher, U., Koriche, S.A., Kroonenberg, S.B., Lordkipanidze, D., Oms, O., Rausch, L. Singarayer, J., Stoica, M., van de Velde, S., Titov, V.V., Wesselingh, F.P., 2019 Quaternary time scales for the Pontocaspian domain: interbasinal connectivity and faunal evolution. Earth Sci. Rev. 188, 1-40. https://doi.org/10.1016/ j.earscirev.2018.10.013.

Kroonenberg, S.B., Alekseevski, N.I., Aliyeva, E.G.M., Allen, M.B., Aybulatov, D.N., Baba-Zadeh, A., Badyukova, E.N., Davies, C.E., Hinds, D.J., Hoogendoorn, R.M., Huseynov, D., Ibrahimov, B., Mamedov, P., Overeem, I., Rusakov, G.V., Suleymanov, S., Svitoch, A.A., Vincent, S.J., 2005. Two deltas, two basins, one river, one sea:The modern Volga delta as an analogue of the Neogene Productive Series, South Caspian Basin. In: Giosan, L., Bhattacharya, J.P. (Eds.), River Deltas-Concepts, Models and Examples, pp. 231-255.

Laskarev, V., 1924. Sur les equivalentes du Sarmatien supérieur en Serbie. Recueil de traveaux ofert a M. Jovan Cvijic par ses amis et collaborateurs, pp. 73-85.

Magyar, I., Radivojević, D., Sztanó, O., Synak, R., Ujszászi, K., Pócsik, M., 2013. Progradation of the paleo-Danube shelf margin across the pannonian basin during the late Miocene and early Pliocene. Glob. Planet. Chang. 103, 168-173. https:// doi.org/10.1016/j.gloplacha.2012.06.007.

Mangino, S., Priestley, K., 1998. The crustal structure of the southern Caspian region. Geophys. J. Int. 133 (3), 630-648. https://doi.org/10.1046/j.1365246X.1998.00520.x.

Markova, L.P., 1962. Stratigraphy of Pliocene Deposits of the Oil Areas of the West Turkmenia. Printing house of the Academy of Sciences of the Turkmen SSR, Ashgabat.

McFadden, P.L., McElhinny, M.W., 1990. Classification of the reversal test in palaeomagnetism. Geophys. J. Int. 103 (3), 725-729. https://doi.org/10.1111/j.1365246X.1990.tb05683.x.

Mordukhai-Boltovskoi, 1964. Caspian fauna beyond the Caspian Sea. Int. Revue ges. Hydrobiol. Hydrogr. 49 (1), 139-176. https://doi.org/10.1002/iroh.19640490105.

Morton, A., Allen, M., Simmons, M., Spathopoulos, F., Still, J., Hinds, D., IsmailZadeh, A., Kroonenberg, S., 2003. Provenance patterns in a neotectonic basin: Pliocene and Quaternary sediment supply to the South Caspian. Basin Res. 15 (3), 321-337. https://doi.org/10.1046/j.1365-2117.2003.00208.x.

Mullender, T.A.T., Frederichs, T., Hilgenfeldt, C., Groot, L.V. de, Fabian, K., Dekkers, M.J., 2016. Automated paleomagnetic and rock magnetic data acquisition with an in-line horizontal "2G" system. Geochem. Geophys. Geosyst. 17 (9), 3546-3559. https://doi.org/10.1002/2016GC006436.

Mullender, T.A.T., Velzen, A.J., Dekkers, M.J., 1993. Continuous drift correction and separate identification of ferrimagnetic and paramagnetic contributions in thermomagnetic runs. Geophys. J. Int. 114 (3), 663-672. https://doi.org/10.1111/ j.1365-246X.1993.tb06995.x.

Muratov, M.V., Nevesskaya, L.A. (Eds.), 1986. Stratigraphy of the USSR: the Neogene Sytem 1. Nedra, Moscow.

Nadirov, R.S., Bagirov, E., Tagiyev, M., Lerche, I., 1997. Flexural plate subsidence, sedimentation rates, and structural development of the super-deep South Caspian Basin. Mar. Pet. Geol. 14 (4), 383-400. https://doi.org/10.1016/S02648172(96)00054-2.

Nevesskaja, L.A., 2007. History of the genus Didacna (Bivalvia: Cardiidae). Paleontol. J. 41 (9), 861-949. https://doi.org/10.1134/S0031030107090018.

Nevesskaya, L.A., 1958. Quaternary marine molluks of Turkmenia. In: Proceedings of the Geological Institute, Academy of Sciences of the USSR, vol. 65.

Nevesskaya, L.A., Goncharova, I.A., Ilyina, L.B., Paramonova, N.P., Khondkarian, S.O., 2003. The Neogene stratigraphic scale of the eastern Paratethys. Stratigr. Geol. Correl. 11 (2), 105-127.

Nevesskaya, L.A., Kovalenko, E.I., Beluzhenko, E.V., Popov, S.V., Goncharova, I.A., Danukalova, G.A., Zhidovinov, I.Y., Zaytsev, A.V., Zastrozhnov, A.S., Ilyina, L.B., Paramonova, N.P., Pinchuk, T.N., Pismennaya, N.S., Agadjanian, A.K. Lopatin, A.V., Trubikhin, V.M. (Eds.), 2004. Explanatory Letter to the Regional Unified Stratigraphic Scheme of Neogene Deposits of the Southern Regions of the European Part of Russia (Moscow).

Nevesskaya, L.A., Trubikhin, V.M., 1984. History of the Caspian basin and its mollusc fauna in the late Pliocene - early Pleistocene. In: Kamaletdinov, M.A., Yakhimovich, V.L. (Eds.), Antropogen of Eurasia. Nauka, Moscow, pp. 19-27. 
Palcu, D.V., Popov, S.V., Golovina, L.A., Kuiper, K.F., Liu, S., Krijgsman, W., 2019. The shutdown of an anoxic giant: magnetostratigraphic dating of the end of the Maikop Sea. Gondwana Res. 67, 82-100. https://doi.org/10.1016/ j.gr.2018.09.011.

Paramonova, N.P., 1994. History of Sarmatian and Akchagylian Bivalves. Nauka, Moscow.

Pevzner, M.A., 1986. Stratigraphy of the Middle Miocene - Pliocene of the South Europe (Based on Paleomagnetic Data). Moscow Dissertation.

Piper, J.D.A., Grant, S., 1989. A palaeomagnetic test of the axial dipole assumption and implications for continental distribution through geological time. Phys. Earth Planet. Inter. 55 (1-2), 37-53. https://doi.org/10.1016/0031-9201(89) 90232-X.

Popov, G.I., 1970. Apsheronian deposits of the Azov Sea Basin. Sov. Geol. (13).

Popov, S.V., Antipov, M.P., Zastrozhnov, A.S., Kurina, E.E., Pinchuk, T.N., 2010. sealevel fluctuations on the northern shelf of the eastern Paratethys in the Oligocene-Neogene. Stratigr. Geol. Correl. 18 (2), 200-224. https://doi.org/ 10.1134/S0869593810020073.

Popov, S.V., Shcherba, I.G., Ilyina, L.B., Nevesskaya, L.A., Paramonova, N.P., Khondkarian, S.O., Magyar, I., 2006. Late Miocene to Pliocene palaeogeography of the Paratethys and its relation to the Mediterranean. Palaeogeogr. Palaeoclimatol. Palaeoecol. 238 (1-4), 91-106. https://doi.org/10.1016/ j.palaeo.2006.03.020.

Richards, K., van Baak, C.G.C., Athersuch, J., Hoyle, T.M., Stoica, M., Austin, W.E.N., Cage, A.G., Wonders, A.A.H., Marret, F., Pinnington, C.A., 2018. Palynology and micropalaeontology of the Pliocene - Pleistocene transition in outcrop from the western Caspian Sea, Azerbaijan: potential links with the Mediterranean, Black Sea and the Arctic Ocean? Palaeogeogr. Palaeoclimatol. Palaeoecol. 511, 119-143. https://doi.org/10.1016/j.palaeo.2018.07.018.

Rögl, F., 1999. Short note Mediterranean and Paratethys. Facts and hypotheses of an Oligocene to Miocene paleogeography (short overview). Geol. Carpathica 50 (4), 339-349.

Rozyeva, T.R., 1971. In: Vyalov, O.S. (Ed.), Composition and Stratigraphic Distribution of the Tertiary Ostracods of Turkmenia. Fossil Ostracoda, Jerusalem, pp. 169-178.

Saltykov, V.F., 2011. Pleistocene stratigraphy for the north caspan area. Bull. Com. Study Quat. 71, 95-111.

Schulz, H., Bechtel, A., Sachsenhofer, R., 2005. The birth of the Paratethys during the early Oligocene: from Tethys to an ancient Black Sea analogue? Glob. Planet. Chang. 49 (3-4), 163-176. https://doi.org/10.1016/j.gloplacha.2005.07.001.

Sedaikin, V.M., 1988. Reference Sections of the Quaternary Sediments of the NorthWestern Pre-Caspian. VINITI(1594-B-88), p. 190.

Semenenko, V.N., Pevzner, M.A., 1979. Correlation of Miocene and Pliocene of the pont-caspian on the biostratigraphic and paleomagnetic data. Proc. USSR Acad. Sci. Geol. Ser. 1, 5-15.

Shantser, E.V. (Ed.), 1982. Stratigraphy of the USSR: Quaternary System 1. Nedra, Moscow.

Sidnev, A.V., 1985. The History of the Pliocene Hydrographic System in Pre-urals. Nauka, Moscow.

Sjögren, H., 1891. Preliminära meddelanden am de kaukasika naftafälten. Geo. Fören. i Stock. Förhandl 13 (2-3), 1-55.

Stoica, M., Lazăr, I., Krijgsman, W., Vasiliev, I., Jipa, D., Floroiu, A., 2013. Paleoenvironmental evolution of the East Carpathian foredeep during the late Miocene-early Pliocene (Dacian basin; Romania). Glob. Planet. Chang. 103, 135-148. https://doi.org/10.1016/j.gloplacha.2012.04.004.

Svitoch, A., Yanina, T., 1997. Quaternary Deposits of the Caspian Sea Coasts. RASKhN, Moscow.

Svitoch, A.A., Yanina, T.A., 2007. Data on stratotypes of the neopleistocene-holocene regional and local subdivisions in the Caspian region. Stratigr. Geol. Correl. 15 (5), 536-552. https://doi.org/10.1134/S0869593807050061.

Svitoch, A.A., Yanina, T.A., Novikova, N.G., Sobolev, V.M., Khomenko, A.A., 2010. The
Pleistocene of the Manych: (Structure and Evolution). Geographical faculty MSU, Moscow.

Taktakishvili, I.G., 1977. Towards the Pliocene History of Paratethian Mollusk Fauna. Metsniereba, Tbilisi.

Tauxe, L., 2010. Essentials of Paleomagnetism. University of California Press, Berkeley.

Trubikhin, V.M., 1977. Paleomagnetism and Stratigraphy of Akchagylian Deposits of West Turkmenia (Moscow).

van Baak, C.G.C. 2015. Mediterranean-Paratethys Connectivity during the Late Miocene to Recent: Unravelling Geodynamic and Paleoclimatic Causes of SeaLevel Change in Semi-isolated Basins. Doctoral dissertation. Utrecht University, Utrecht (Doctoral dissertation).

van Baak, C.G.C., Grothe, A., Richards, K., Stoica, M., Aliyeva, E., Davies, G. Kuiper, K.F., Krijgsman, W., 2019. Flooding of the Caspian Sea at the intensification of northern hemisphere glaciations. Glob. Planet. Chang. 174, 153-163. https://doi.org/10.1016/j.gloplacha.2019.01.007.

van Baak, C.G.C., Krijgsman, W., Magyar, I., Sztanó, O., Golovina, L.A., Grothe, A Hoyle, T.M., Mandic, O., Patina, I.S., Popov, S.V., Radionova, E.P., Stoica, M., Vasiliev, I., 2017. Paratethys response to the Messinian salinity crisis. Earth Sci. Rev. 172, 193-223. https://doi.org/10.1016/j.earscirev.2017.07.015.

van Baak, C.G.C., Vasiliev, I., Stoica, M., Kuiper, K.F., Forte, A.M., Aliyeva, E., Krijgsman, W., 2013. A magnetostratigraphic time frame for Plio-Pleistocene transgressions in the South Caspian Basin, Azerbaijan. Glob. Planet. Chang. 103, 119-134. https://doi.org/10.1016/j.gloplacha.2012.05.004.

Vasiliev, I., Franke, C., Meeldijk, J.D., Dekkers, M.J., Langereis, C.G., Krijgsman, W. 2008. Putative greigite magnetofossils from the Pliocene epoch. Nat. Geosci. 1 (11), 782-786. https://doi.org/10.1038/ngeo335.

Vekilov, B.G., 1969. Anthropogenic Deposits of North-Eastern Azerbaijan. ELM, Baku. Vereshchagin, V.N. (Ed.), 1982. Stratigraphic Dictionary of the USSR: Paleogene, Neogene, Quternary System. Nedra, Leningrad.

Vincent, S.J., Davies, C.E., Richards, K., Aliyeva, E., 2010. Contrasting Pliocene fluvia depositional systems within the rapidly subsiding South Caspian Basin; a case study of the palaeo-Volga and palaeo-Kura river systems in the Surakhany Suite, Upper Productive Series, onshore Azerbaijan. Mar. Pet. Geol. 27 (10) 2079-2106. https://doi.org/10.1016/j.marpetgeo.2010.09.007.

Yakhimovich, V.L., Suleymanova, F.I., 1981. Magnetostratigraphic section of the Pliocene and lower Pleistocene of the non-glacial zone of the pre-urals. Bull. Comm. Study Quat. Period (51), 31-37.

Yakhimovich, V.L., Suleymanova, F.I., Danukalova, G.A., Popova-Lvova, M.G. Yakovlev, A.G., Akhlestina, E.F., Nemkova, V.K., Alimbekova, L.I., 2000. The Pliocene and Pleistocene Reference Section Domashkinskie Vershiny. Gilem, Ufa.

Yanina, T.A., 2012. Neopleistocene of the Pontocaspian Region: Biostratigraphy, Palaeogeography and Correlation. Geographical faculty MSU, Moscow.

Yanina, T.A., 2013. Biostratigraphy of the middle and upper Pleistocene of the caspian region. Quat. Int. 284, 85-97. https://doi.org/10.1016/ j.quaint.2012.02.008.

Yanko, V.V., 1989. Quaternary Foraminifera of the Pontocaspian Region. Doctoral thesis. Odessa (Doctoral thesis).

Zastrozhnov, A.S., Shkatova, V.K., Minina, E.A., Tarnogradskiy, V.D., Astakhov, V.I. Gusev, E.A., 2013. Map of Quaternary Deposits of the Russian Federation. Scale 1:250000: Explanatory Letter. Ministry of Nature of Russia, Rosnedra, VSEGEI. All Russian Research Institute of Geology and Mineral Resources of the Ocean, Saint Petersburg.

Zonenshain, L.P., Le Pichon, X., 1986. Deep basins of the Black Sea and Caspian Sea as remnants of Mesozoic back-arc basins. Tectonophysics 123, 181-211.

Zubakov, V.A. (Ed.), 1974. Geochronology of the USSR 3. Nedra, Leningrad (The Late Pliocene and Quaternary).

Zubakov, V.A., Borzenkova, I.I., 1990. Global Palaeoclimate of the Late Cenozoic. Developments in Palaeontology and Stratigraphy, vol. 12. Elsevier, Amsterdam. 